\title{
Effect of salinity on mercury methylating benthic microbes and their activities in Great Salt Lake, Utah
}

\section{Authors: Eric S. Boyd, Ri-Qing Yu, Tamar Barkay, Trinity L. Hamilton, Bonnie K. Baxter, David L. Naftz, and Mark Marvin-DiPasquale}

NOTICE: this is the author's version of a work that was accepted for publication in Science of the Total Environment Changes resulting from the publishing process, such as peer review, editing, corrections, structural formatting, and other quality control mechanisms may not be reflected in this document. Changes may have been made to this work since it was submitted for publication. A definitive version was subsequently published in Science of the Total Environment, VOL\# 581-582, (March 2017)] DOI\#10.1016/j.scitotenv.2016.12.157

Boyd, Eric S., Ri-Qing Yu, Tamar Barkay, Trinity L. Hamilton, Bonnie K. Baxter, David L. Naftz, and Mark Marvin-DiPasquale. "Effect of salinity on mercury methylating benthic microbes and their activities in Great Salt Lake, Utah." Science of the Total Environment 581-582 (March 2017): 495-506. DOI: 10.1016/j.scitotenv.2016.12.157.

Made available through Montana State University's ScholarWorks scholarworks.montana.edu 


\title{
Effect of salinity on mercury methylating benthic microbes and their activities in Great Salt Lake, Utah
}

\author{
Eric S. Boyd ${ }^{\mathrm{a}, *}$, Ri-Qing Yu ${ }^{\mathrm{b}, 1}$, Tamar Barkay ${ }^{\mathrm{b}}$, Trinity L. Hamilton ${ }^{\mathrm{c}}$, Bonnie K. Baxter ${ }^{\mathrm{d}}$, \\ David L. Naftz ${ }^{\mathrm{e}}$, Mark Marvin-DiPasquale ${ }^{\mathrm{f}}$ \\ a Department of Microbiology and Immunology, Montana State University, Bozeman, MT 59717, United States \\ b Department of Biochemistry and Microbiology, Rutgers University, New Brunswick, NJ 08901, United States \\ c Department of Biological Sciences, University of Cincinnati, Cincinnati, OH 45221, United States \\ d Department of Biology, Westminster College, Salt Lake City, UT 84105, United States \\ e United States Geological Survey, Helena, MT 59601, United States \\ ${ }^{\mathrm{f}}$ United States Geological Survey, Menlo Park, CA 94025, United States
}

G R A P H I C A L A B S T R A C T

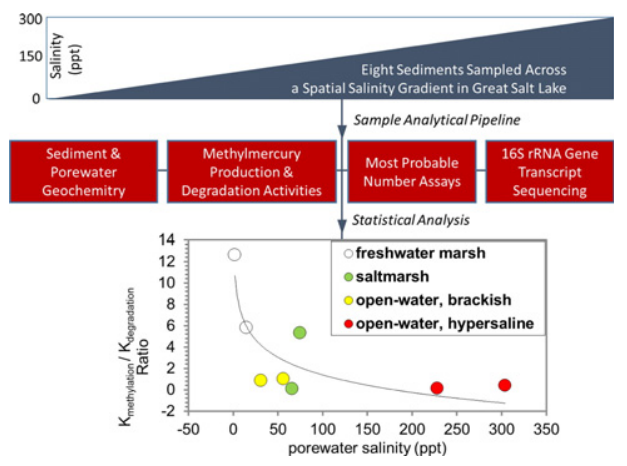

A B S T R A C T

Surface water and biota from Great Salt Lake (GSL) contain some of the highest documented concentrations of total mercury (THg) and methylmercury ( $\mathrm{MeHg}$ ) in the United States. In order to identify potential biological sources of $\mathrm{MeHg}$ and controls on its production in this ecosystem, $\mathrm{THg}$ and $\mathrm{MeHg}$ concentrations, rates of $\mathrm{Hg}$ (II)-methylation and $\mathrm{MeHg}$ degradation, and abundances and compositions of archaeal and bacterial 16 rRNA gene transcripts were determined in sediment along a salinity gradient in GSL. Rates of $\mathrm{Hg}$ (II)-methylation were inversely correlated with salinity and were at or below the limits of detection in sediment sampled from areas with hypersaline surface water. The highest rates of $\mathrm{Hg}(\mathrm{II})$-methylation were measured in sediment with low porewater salinity, suggesting that benthic microbial communities inhabiting less saline environments are supplying the majority of MeHg in the GSL ecosystem. The abundance of $16 \mathrm{~S}$ rRNA gene transcripts affiliated with the sulfate reducer Desulfobacterium sp. was positively correlated with $\mathrm{MeHg}$ concentrations and $\mathrm{Hg}$ (II)-methylation rates in sediment, indicating a potential role for this taxon in $\mathrm{Hg}$ (II)-methylation in low salinity areas of GSL. Reactive inorganic $\mathrm{Hg}$ (II) (a proxy used for $\mathrm{Hg}$ (II) available for methylation) and $\mathrm{MeHg}$ concentra-tions were inversely correlated with salinity. Thus, constraints imposed by salinity on $\mathrm{Hg}(\mathrm{II})$-methylating popu-lations and the availability of $\mathrm{Hg}(\mathrm{II})$ for methylation are inferred to result in higher $\mathrm{MeHg}$ production potentials in lower salinity environments. Benthic microbial MeHg degradation was also most active in lower salinity

environments. Collectively, these results suggest an important role for sediment anoxia and microbial sulfate reducers in the production of MeHg in low salinity GSL sub-habitats and may indicate a role for salinity in constraining $\mathrm{Hg}$ (II)-methylation and $\mathrm{MeHg}$ degradation activities by influencing the availability of $\mathrm{Hg}(\mathrm{II})$ for methylation. 


\section{Introduction}

Great Salt Lake (GSL) is the largest lake in the western United States and the fourth largest terminal lake in the world $\left(52,000 \mathrm{~km}^{2}\right)$ (Fig. 1) (Keck and Hassibe, 1979). With over 200 avian species known to inhabit GSL over the course of a year, it has been suggested to be the most important inland shorebird site in North America with millions of birds visiting annually (Aldrich and Paul, 2002; Paul and Manning, 2008). A recent study of the most abundant avian species that utilize GSL revealed diets that consist predominantly of brine shrimp (Artemia franciscana) and brine flies and their larvae (Ephydra spp.) (Roberts, 2013), which themselves feed on phytoplankton and periphyton (Barnes and Wurtsbaugh, 2015; Collins, 1980; Wurtsbaugh and Gliwicz, 2001). Thus, carbon and energy from primary producers (phytoplankton and periphyton) are channeled to bird populations through invertebrate grazers.

Some of the highest concentrations of total mercury ( $\mathrm{THg}$ ) and methylmercury (MeHg) documented in the United States are found in the waters of GSL (Naftz et al., 2008). This is due, at least in part, to GSL being a terminal lake (Tayler et al., 1980) but also because of elevated rates of atmospheric $\mathrm{Hg}$ deposition in the region (Naftz et al., 2009; Peterson and Gustin, 2008). As a consequence, biomass of periphyton, Artemia, and Ephydra in GSL was shown to contain elevated concentrations of THg (Peterson and Gustin, 2008; Wurtsbaugh et al., 2011).
Moreover, muscle tissues from common goldeneye duck, along with several other bird species, were shown to contain THg at concentrations up to 42-fold greater than Ephydra, a common food source for these birds (Scholl and Ball, 2005; Vest et al., 2009; Wurtsbaugh et al., 2011). Further, birds and brine flies with elevated THg concentrations were located proximal to waters with the highest measured MeHg concentrations in GSL (Johnson et al., 2015). Together, these observations suggest bioaccumulation of $\mathrm{Hg}$ in the form of $\mathrm{MeHg}$ (Naftz et al., 2008) which typically enters the base of aquatic food webs as a result of uptake by primary producers (Boyd et al., 2009; Mason et al., 1996; Pickhardt and Fisher, 2007). Bioaccumulation occurs in higher trophic levels (periphyton, birds) when consumers absorb $\mathrm{MeHg}$ from this food source and then respire carbon faster than they excrete the metal (Watras et al., 1998).

The formation of $\mathrm{MeHg}$ from inorganic $\mathrm{Hg}$ in aquatic environments occurs under anoxic conditions and is catalyzed by a diverse group of anaerobes, including those involved in sulfate reduction, iron reduction, methanogenesis, and fermentation (Compeau and Bartha, 1985; Fleming et al., 2006; Gilmour and Henry, 1991; Gilmour et al., 2013; Parks et al., 2013; Podar et al., 2015). While GSL is primarily a sodium chloride lake (Oren, 2013), concentrations of sulfate are high (Spencer et al., 1985), representing up to $7 \%$ of the total soluble salt (Wurtsbaugh et al., 2011). This fact coupled with the abundance $\left(10^{7}\right.$ to $10^{8}$ cells $\mathrm{cm}^{-3}$ sediment) of sulfate reducing bacteria (SRB) and

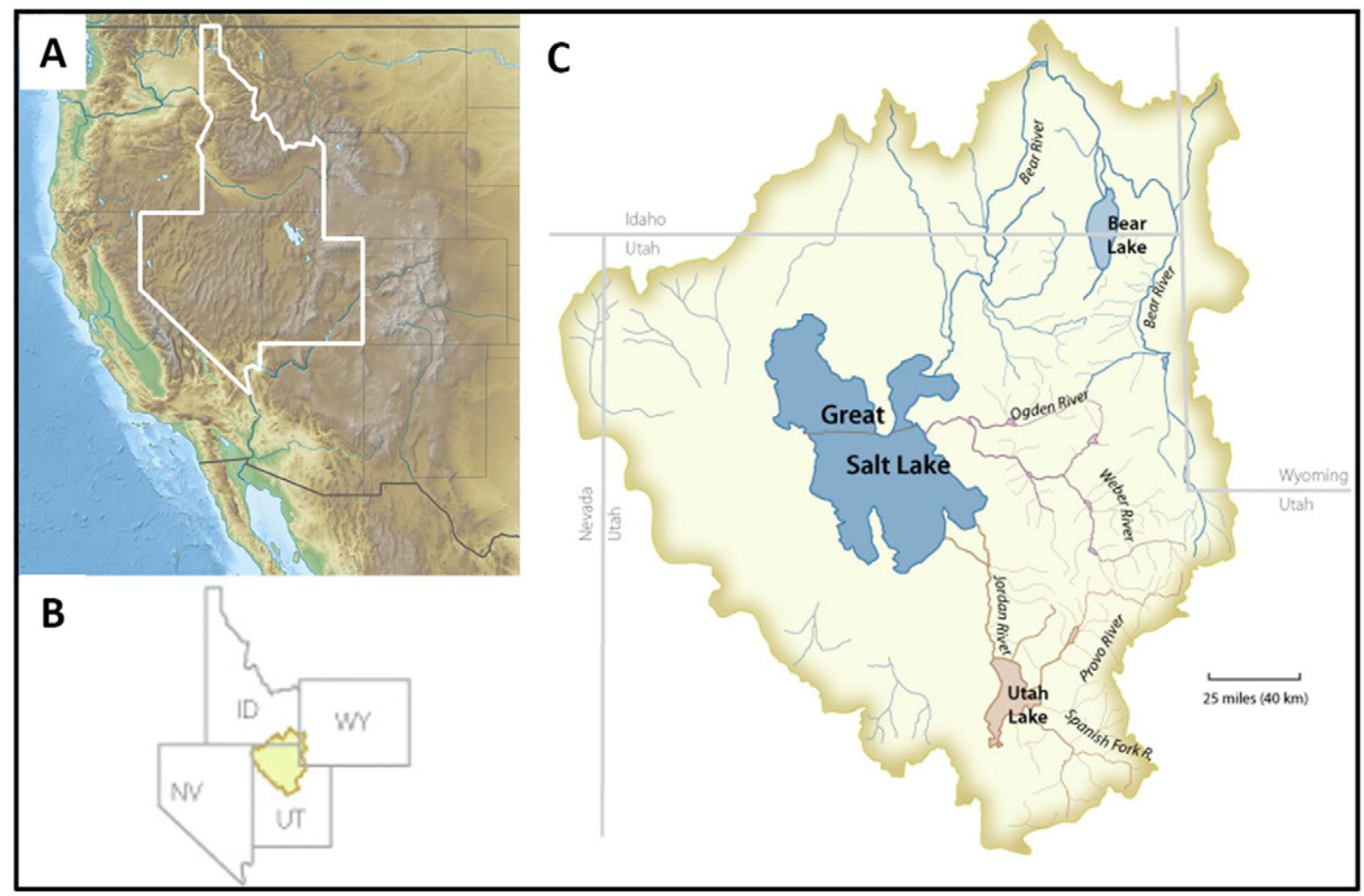

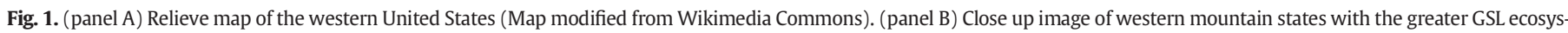

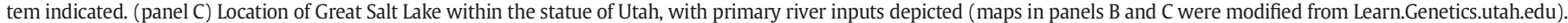


high rates of sulfate reduction (SR) in GSL sediments (Brandt et al., 2001) have led to the hypothesis that SRB are the primary $\mathrm{Hg}$ (II)-methylators in GSL (Jones and Wurtsbaugh, 2014; Naftz et al., 2009; Wurtsbaugh et al., 2011).

The ecological success of SRB in GSL can be partially attributed to construction of a railroad causeway across GSL, which has historically restricted water flow between the higher salinity North Arm (NA) and the lower salinity South Arm (SA) (Baxter et al., 2005; Cannon and Cannon, 2002). The NA salinity is typically at saturation $[\sim 5 \mathrm{M}, 270-$ $300 \mathrm{~g} / \mathrm{L}$ total dissolved solids (TDS)], whereas salinity in the SA surface brine is substantially lower ( $2.5 \mathrm{M}, 140-150 \mathrm{~g} / \mathrm{L}$ TDS) due to freshwater inputs from four rivers (Baxter et al., 2005). Seepage of the denser high-salinity water through the causeway and culverts can create a deep brine layer (DBL) which does not mix well with the upper less dense layer (Meuser et al., 2013; Naftz et al., 2009). Sedimentation of planktonic cells and aerobic respiration of their biomass results in anoxic conditions in the DBL when it is present (Boyd et al., 2014; Jones and Wurtsbaugh, 2014; Meuser et al., 2013), a characteristic that promotes SR activity (Rabus et al., 2013). Previous studies have shown that rates of SR vary dramatically in GSL as a function of salinity in the overriding water column, with higher rates detected in sediment overlain by the anoxic DBL (Brandt et al., 2001). Consistent with the role of SRB in $\mathrm{Hg}$ (II)-methylation in anoxic GSL environments, high MeHg concentrations have been detected in the sulfidic and anoxic DBL waters, where up to $80 \%$ of total $\mathrm{Hg}$ was found to be in the MeHg form (Naftz et al., 2008). Limited mixing of MeHg-rich DBL water with upper brine layer (UBL) water during wind events (Beisner et al., 2009; Naftz et al., 2014 ) is thought to allow for entry of MeHg into phytoplankton, periphyton, and oxic food webs in the UBL (Johnson et al., 2015; Jones and Wurtsbaugh, 2014).

SRB have historically been classified by cell shape, motility, GC content of DNA, distribution of the redox active cofactors desulfovirin and cytochromes, optimal growth temperature, and complete versus incomplete oxidation of organic compounds (Castro et al., 2000). SRB capable of terminally oxidizing acetate to $\mathrm{CO}_{2}$ are apparently intolerant of salinities $>120 \mathrm{~g} / \mathrm{L}$, whereas SRB that incompletely oxidize organic substrates to acetate are more tolerant of salinity at levels approaching $300 \mathrm{~g} / \mathrm{L}$ (Oren, 2013). Complete and incomplete oxidizer SRB differ in their pathways of carbon metabolism. In complete oxidizer SRB, the acetyl CoA pathway is thought to play a key role in supplying methylated $\mathrm{C} 1$ intermediates for transfer to inorganic $\mathrm{Hg}$ (II) (Ekstrom and Morel, 2008; Ekstrom et al., 2003) by a corrinoid-containing protein complex termed HgcAB (Parks et al., 2013). Together, these observations suggest that salinity may influence the spatial distribution of complete versus incomplete SRB in GSL, which in turn may affect the pathways by which $\mathrm{C} 1$ intermediates for $\mathrm{Hg}$ (II)-methylation are generated, $\mathrm{Hg}$ (II)methylation activity, and accumulation of $\mathrm{MeHg}$ in the food chain.

In this work we sought to identify the biogeochemical controls and the role of SRB and other $\mathrm{Hg}$ methylating guilds on $\mathrm{MeHg}$ formation in GSL sediment. We hypothesized that observed differences in MeHg concentrations and its production along salinity gradients in GSL are due to differential constraints imposed by salinity on the ecology of complete and incomplete oxidizing SRB (Oren, 2013) as well as the influence of salinity and redox conditions on the bioavailability of $\mathrm{Hg}$ (II) (Barkay et al., 1997; Marvin-DiPasquale et al., 2014). We tested these hypotheses through an integration of data derived from geochemical analyses, microcosm-based process rate measurements, most probable number estimates, and molecular characterization of 16S rRNA gene transcripts in sediment collected along a 30\% salinity gradient.

\section{Materials and methods}

\subsection{Site selection, sample collection, and in-field geochemical analyses}

During November 2011, benthic sediment sampling occurred at eight locations. These locations span the spatial salinity gradient in the
SA and NA of GSL (Fig. 2, Table 1) and represent four dominant habitat types within the GSL study area: freshwater marsh (Bear River Ponds 5C and 3E), saltmarsh (South Shore and Ogden Bay), brackish open-water (Farmington Bay and Bear River Bay), and hypersaline (North Basin and Gunnison Island). Sediment was collected in deep water from a boat using a box-core, or in shallow settings (wetlands) by hand, with the top $0-2 \mathrm{~cm}$ surface sediment interval being sub-sampled using acidclean polycarbonate core rings. In-field measurements included sediment temperature, $\mathrm{pH}$, and oxidation-reduction (redox) potential. Sediment collected for mercury speciation, subsequent microbial rate assays, and ancillary sediment and porewater constituents, was transferred to acid-cleaned mason jars in the field and stored chilled until overnight shipment to the United State Geological Survey (USGS) laboratory (Menlo Park, CA) for further processing. A split of chilled sediment was sent to Rutgers University (New Brunswick, NJ) for use in most probable number (MPN) and activity assays. A separate sediment sub-sample, collected for molecular work, was transferred into presterilized microfuge tubes using pre-sterilized disposable spatula, and field-frozen using dry ice until being shipped (frozen) to Montana State University (Bozeman, MT) for further processing.

\subsection{Mercury speciation and ancillary sediment and porewater parameters}

Field chilled sediment was subsequently further sub-sampled in an $\mathrm{N}_{2}$ flushed glove bag at the USGS laboratory (Menlo Park, CA) for a

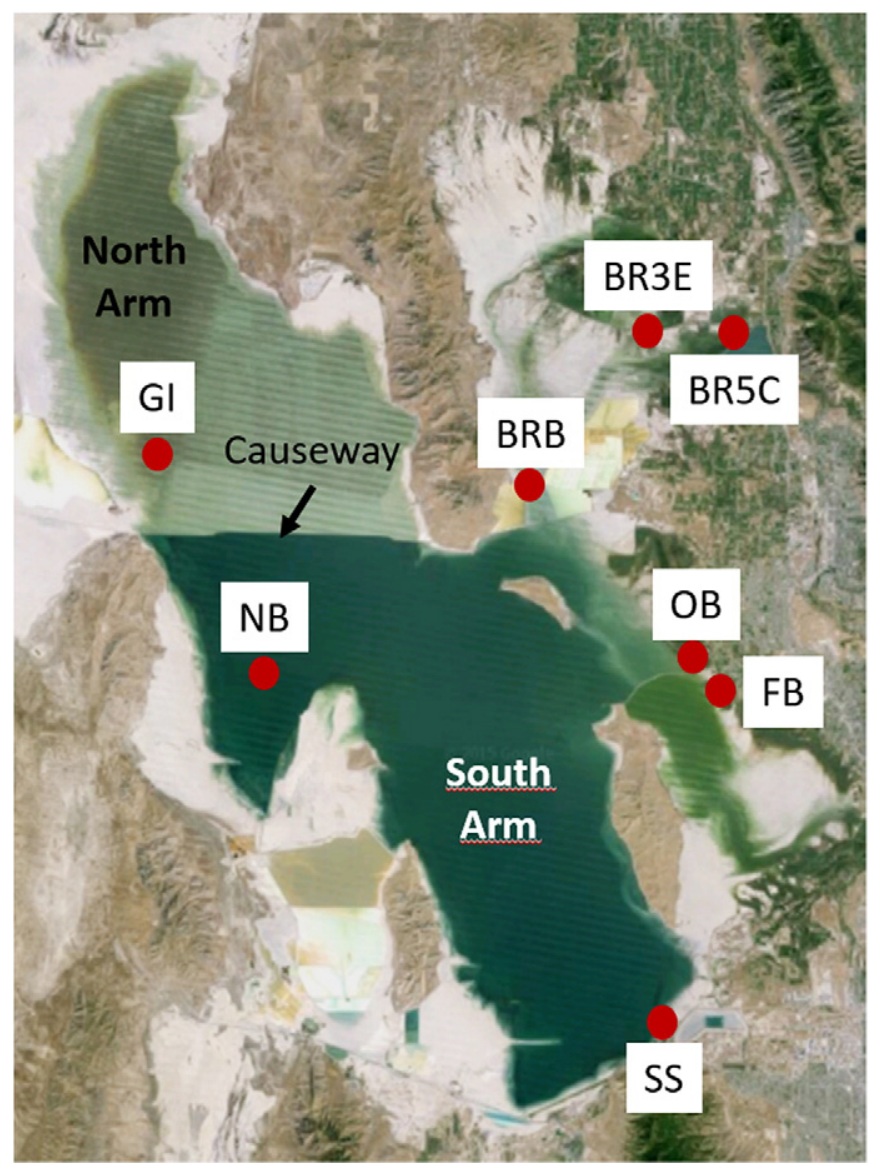

Fig. 2. Great Salt Lake sediment sampling sites during November 2011. The railroad causeway separating the lake South Arm (SA) and North Arm (NA) is indicated. GPS coordinates for each of the sampling locations are provided in Table 1. Site abbreviations: BR5C, Bear River Pond 5C; BR3E, Bear River Pond 3E; SS, South Shore; OB, Ogden Bay; FB, Farmington Bay; BRB, Bear River Bay; NB, North Basin; GI, Gunnison Island. Map modified from a Google Earth image. 
Table 1

Description of sample collection sites.

\begin{tabular}{|c|c|c|c|c|c|c|c|c|}
\hline Site name & Description & Collection date & $\begin{array}{l}\text { Latitude } \\
(\mathrm{N})^{\mathrm{a}}\end{array}$ & $\begin{array}{l}\text { Longitude } \\
(\mathrm{W})^{\mathrm{a}}\end{array}$ & $\begin{array}{l}\text { Porewater salinity } \\
(\%)^{\mathrm{b}}\end{array}$ & $\begin{array}{l}\text { Surface water temp. } \\
\left({ }^{\circ} \mathrm{C}\right)\end{array}$ & $\begin{array}{l}\text { Sediment temp. } \\
\left({ }^{\circ} \mathrm{C}\right)^{\mathrm{b}}\end{array}$ & $\begin{array}{l}\text { Sediment } \\
\mathrm{pH}\end{array}$ \\
\hline Bear River - Pond 5C & Freshwater & $11 / 10 / 12$ & 41.42300 & 112.08691 & 0.2 & 6.5 & 4.7 & 7.17 \\
\hline Bear River - Pond 3E & Freshwater & $11 / 10 / 12$ & 41.41688 & 112.21879 & 1.5 & 8.2 & 8.7 & 7.56 \\
\hline Farmington Bay & Brackish & $11 / 7 / 12$ & 41.08733 & 112.13966 & 3.1 & 8.2 & 9.7 & 7.91 \\
\hline Bear River Bay & Brackish & $11 / 9 / 12$ & 41.24827 & 112.34637 & 5.6 & 3.3 & N.A. & 7.3 \\
\hline South Shore & Saltmarsh & $11 / 7 / 12$ & 40.75543 & 112.18936 & 6.6 & 5.1 & 4.7 & 8.31 \\
\hline Ogden Bay & Saltmarsh & $11 / 7 / 12$ & 41.08979 & 112.14604 & 7.5 & 8.6 & 6.5 & 7.48 \\
\hline North Basin & Hypersaline & $11 / 9 / 12$ & 41.11222 & 112.64056 & 22.8 & 16.3 & N.A. & 7.14 \\
\hline Gunnison Island & Hypersaline & $11 / 14 / 12$ & 41.22306 & 112.84370 & 30.4 & 9.2 & 10.1 & 6.96 \\
\hline
\end{tabular}

Abbreviations: N.A., not available.

a WGS84 datum.

b Determined via refractometry.

suite of parameters, including total mercury ( $\mathrm{THg}$ ), $\mathrm{MeHg}$, and reactive divalent inorganic mercury $\left(\mathrm{Hg}(\mathrm{II})_{\mathrm{R}}\right)$, total reduced sulfur (TRS), acid extractable ferrous iron ( $\left.\mathrm{Fe}(\mathrm{II})_{\mathrm{AE}}\right)$, amorphous ferric iron $\left(\mathrm{Fe}(\mathrm{III})_{\mathrm{a}}\right)$, and crystalline ferric iron $\left(\mathrm{Fe}(\mathrm{III})_{\mathrm{c}}\right)$. Sediment porewater was obtained via centrifugation and subsequent filtration $(0.45 \mu \mathrm{m})$ in an $\mathrm{N}_{2}$ flushed glove bag, with sub-samples collected and preserved for sulfide $\left(\mathrm{S}^{2-}\right)$, ferrous iron $\left(\mathrm{Fe}^{2+}\right)$, sulfate $\left(\mathrm{SO}_{4}^{2-}\right)$, chloride $\left(\mathrm{Cl}^{-}\right)$, and dissolved organic carbon (DOC). Details on sample preservation and analysis for the above sediment and porewater constituents has been previously documented (Huffman et al., 2012; Marvin-DiPasquale et al., 2008). Sediment porewater salinity was measured using a Vista A366ATC refractometer.

\subsection{Mercury methylation and degradation potentials}

Rate constants for microbial $\mathrm{Hg}$ (II)-methylation ( $\left.\mathrm{k}_{\text {meth }}\right)$ and $\mathrm{MeHg}$ degradation $\left(\mathrm{k}_{\mathrm{deg}}\right)$ were determined by USGS (Menlo Park, CA) in parallel sets of subsamples, using stable isotope $\mathrm{Hg}$ tracer $\left({ }^{202} \mathrm{HgCl}_{2}\right.$ and $\mathrm{Me}^{201} \mathrm{Hg}$, respectively) amendment incubations (at $20^{\circ} \mathrm{C}$ ). Incubations for $\mathrm{k}_{\text {meth }}$ determination were carried out for $5 \mathrm{~h}$, while those for $\mathrm{k}_{\text {deg }}$ determination were carried out for 6 days. For each site, incubations consisted of duplicate samples plus one killed control (flash frozen at time $=0$ ), for both $\mathrm{k}_{\text {meth }}$ and $\mathrm{k}_{\mathrm{deg}}$ determinations. Incubations were arrested via flash freezing in a bath of dry ice/ethanol. MeHg was subsequently extracted via heated $\mathrm{KOH} /$ methanol (Protection, 2011), with $\mathrm{Me}^{200} \mathrm{Hg}$ and $\mathrm{Me}^{201} \mathrm{Hg}$ quantified via isotope dilution ICP-MS. Pseudo first-order rate constants for $\mathrm{Hg}$ (II)-methylation were calculated as: $\mathrm{k}_{\text {meth }}=\ln \left(1-\mathrm{f}_{\mathrm{m}}\right) / \mathrm{t}$, where $\ln$ is the natural logarithm function, $\mathrm{f}_{\mathrm{m}}$ equals the fraction of ${ }^{202} \mathrm{Hg}$ (II) converted to $\mathrm{Me}^{202} \mathrm{Hg}$, and t equals the incubation time in days. Daily $\mathrm{Hg}(\mathrm{II})$-methylation potential (MPP) rates (units $=\mathrm{ng} / \mathrm{g}$ dry sediment $/ \mathrm{d}$ ) were then calculated as: MPP $=$ $\mathrm{Hg}(\mathrm{II})_{\mathrm{R}}-\mathrm{Hg}(\mathrm{II})_{\mathrm{R}} \cdot \operatorname{EXP}\left(-\mathrm{k}_{\text {meth }} \cdot \mathrm{t}\right)$, where $t=1.0$ day and $\mathrm{Hg}(\mathrm{II})_{\mathrm{R}}$ is the independently measured in situ $\mathrm{Hg}(\mathrm{II})_{\mathrm{R}}$ concentration (ng/g dry weight). The total amount of $\mathrm{Hg}$ (II) added to MPP microcosms as part of the ${ }^{200} \mathrm{Hg}$ (II) amendment was $47 \mathrm{ng} \mathrm{g}^{-1}$ of wet sediment, which was comparable to the mean in situ sediment THg concentrations (mean \pm std. dev: $52 \pm 81 \mathrm{ng} \mathrm{g}^{-1}$ wet weight; range = $7-245 \mathrm{ng} \mathrm{g}^{-1}$ wet weight; median $=18 \mathrm{ng} \mathrm{g}^{-1}$ wet weight, $n=8$ ). Pseudo first-order rate constants for $\mathrm{MeHg}$ degradation $\left(\mathrm{k}_{\mathrm{deg}}\right)$ were similarly calculated as: $k_{\mathrm{deg}}=\ln \left(1-\mathrm{f}_{\mathrm{d}}\right) / \mathrm{t}$, where $\mathrm{f}_{\mathrm{d}}$ equals the fraction of $\mathrm{Me}^{201} \mathrm{Hg}$ degraded, and $\mathrm{t}$ equals the incubation time in days. Daily MeHg degradation (MDP) rates (units $=n g^{-1}$ dry sediment/d) are then calculated as: $\mathrm{MDP}=\mathrm{MeHg}_{\text {sed }}-\mathrm{MeHg}_{\text {sed }} \cdot \operatorname{EXP}\left(-\mathrm{k}_{\mathrm{deg}} \cdot \mathrm{t}\right)$, where $t=1.0$ day and independently measured in situ sediment MeHg concentration values ( $\mathrm{ng} \mathrm{g}^{-1}$ dry weight) are used. The total amount of $\mathrm{MeHg}$ added to MDP microcosms as part of the $\mathrm{Me}^{201} \mathrm{Hg}$ amendment was $0.9 \mathrm{ng} \mathrm{g}^{-1}$ of wet sediment, which was just over double the mean in situ sediment $\mathrm{MeHg}$ concentrations (mean \pm std. dev: $0.41 \pm$ $0.35 \mathrm{ng} \mathrm{g}^{-1}$ wet weight; range $=0.04-1.08 \mathrm{ng} \mathrm{g}^{-1}$ wet weight; median $=0.34 \mathrm{ng} \mathrm{g}^{-1}$ wet weight, $n=8$ ).

\subsection{Effect of amendments on MPP}

Sediment samples from Bear River Pond 3E, Bear River Bay, and North Basin were homogenized and prepared as slurry microcosms in serum bottles in an anaerobic chamber. In addition to the MPP rates measured above via ${ }^{200} \mathrm{Hg}$ (II) stable isotope amendment, a separate assessment of MPP was measured (at Rutgers University) using ${ }^{203} \mathrm{HgCl}_{2}$ radiotracer (specific activity of $2.5 \mathrm{Ci} \mathrm{g}^{-1}$; kindly provided by Christy C. Bridges, Mercer University, GA), in microcosms that were preincubated overnight $(18-20 \mathrm{~h})$ prior to the addition of substrate. ${ }^{203} \mathrm{HgCl}_{2}$ was added to slurries at a concentration, $\sim 2.0 \mathrm{ng} \mathrm{g}^{-1}$ wet weight or $10 \mathrm{nM}$, which was lower than the in situ sediment THg level concentrations (see above). Radiolabeled $\mathrm{Me}^{203} \mathrm{Hg}$ was extracted from slurry incubations and $\mathrm{Me}^{203} \mathrm{Hg}$ was quantified by scintillation counting. Potential $\mathrm{Hg}$ methylation rates $\left(\%\right.$ day $\left.^{-1}\right)$ were calculated from results of triplicate samples per treatment. All experimental approaches, employed methods and reagents, and data manipulations were previously described (Hines et al., 2006; Yu et al., 2010; Yu et al., 2012).

To distinguish activities of key $\mathrm{Hg}$ (II)-methylators (i.e., SRB, iron reducing bacteria (FeRB), and methanogens) among benthic microbial communities, microcosms were amended with a series of substrate or inhibitors as previously described (Yu et al., 2010; Yu et al., 2012). Briefly, to examine the role of SRB in $\mathrm{Hg}$ (II)-methylation, an amount of $\mathrm{SO}_{4}^{2-}$ was added to achieve a final concentration that was one-fold greater than the concentrations in sediment porewater of each site (Table 2). Molybdate, an inhibitor of SRB, was added to a separate set of microcosm incubations at the same concentration as $\mathrm{SO}_{4}^{2-}$. With the exception of Farmington Bay ( $0.27 \mathrm{mg}$ amorphous $\mathrm{Fe}^{3+} \mathrm{g}^{-1}$ dry weight), a site not studied in this more detailed analysis of MPP, the sediment amorphous $\mathrm{Fe}^{3+}$ levels across all sites were lower than the detection limit $\left(0.08 \mathrm{mg} \mathrm{g}^{-1}\right.$ dry weight; Table 2$)$. Thus, iron oxide $\left[\mathrm{Fe}(\mathrm{OH})_{3}\right]$ was added to stimulate activities of FeRB at a concentration of $0.04 \mathrm{mg} \mathrm{g}^{-1}$ or one half of the detection limit. Preliminary experiments showed that addition of this amount of $\mathrm{Fe}(\mathrm{OH})_{3}$ stimulated microbial $\mathrm{Hg}$ (II)-methylation. Freshly synthesized $\mathrm{Fe}(\mathrm{OH})_{3}$ was prepared by previously described methods (Cornell and Schwertmann, 2003). To inhibit methanogens, $0.5 \mathrm{mM}$ of 2-bromoethanesulfonate (BES), a concentration used previously (Pak and Bartha, 1998), was added to slurry incubations.

\subsection{Most probable number (MPN) estimates of SRB}

MPN assays were used to estimate the number of viable SRB present in sediments collected from Bear River Pond 3E, Bear River Bay, and North Basin. The employed method was modified from previous studies (Brandt et al., 2001; Widdel and Bak, 1992; Yu et al., 2010). The SRBMPN medium (Widdel and Bak, 1992) was modified by adding resazurin $(2.0 \mathrm{nM})$ and $\mathrm{FeCl}_{2} \cdot 4 \mathrm{H}_{2} \mathrm{O}(1.0 \mathrm{mM})$, the latter of which upon commencement of SR activity forms black FeS precipitates serving 
Table 2

Sediment pore water geochemical measurements.

\begin{tabular}{|c|c|c|c|c|c|c|c|c|c|c|}
\hline \multirow[b]{2}{*}{ Site name } & \multicolumn{5}{|c|}{ Sediment porewater } & \multicolumn{5}{|c|}{ Bulk sediment $^{\mathrm{a}}$} \\
\hline & $\begin{array}{l}\mathrm{SO}_{4}^{2-} \\
(\mathrm{mM})\end{array}$ & $\begin{array}{l}\mathrm{Cl}^{-} \\
(\mathrm{mM})\end{array}$ & $\begin{array}{l}\mathrm{Fe}^{2+} \\
(\mu \mathrm{M})\end{array}$ & $\begin{array}{l}\mathrm{S}^{2-} \\
(\mu \mathrm{M})\end{array}$ & $\begin{array}{l}\text { DOC } \\
(\mathrm{mg} / \mathrm{L})\end{array}$ & $\begin{array}{l}\text { Redox as } \mathrm{E}_{\mathrm{h}} \\
(\mathrm{mV})\end{array}$ & $\begin{array}{l}\text { Total Reduced S } \\
(\mu \mathrm{mol} / \mathrm{g})\end{array}$ & $\begin{array}{l}\text { Acid Extract. } \\
\mathrm{Fe}^{2+} \\
(\mathrm{mg} / \mathrm{g})\end{array}$ & $\begin{array}{l}\text { Amorphous } \mathrm{Fe}^{3+} \\
(\mathrm{mg} / \mathrm{g})\end{array}$ & $\begin{array}{l}\text { Crystalline } \mathrm{Fe}^{3+} \\
(\mathrm{mg} / \mathrm{g})\end{array}$ \\
\hline Bear River - Pond 5C & 0.2 & 13 & 8.5 & 2 & 15 & -134 & 36.3 & 3.02 & $<0.08$ & $<0.08$ \\
\hline Bear River - Pond 3E & 25 & 184 & $<1.4$ & 75 & 63 & -134 & 6.0 & 1.29 & $<0.08$ & 0.60 \\
\hline Farmington Bay & 30 & 468 & $<1.4$ & 34 & 37 & -3 & 9.9 & 2.08 & 0.27 & 0.40 \\
\hline Bear River Bay & 32 & 797 & 2.9 & 2733 & 28 & -163 & 24.4 & 3.59 & $<0.08$ & $<0.08$ \\
\hline South Shore & 421 & 321 & $<1.4$ & 13 & 101 & -29 & 7.9 & 0.13 & $<0.08$ & 0.39 \\
\hline Ogden Bay & 57 & 1271 & $<1.4$ & 3839 & 178 & -227 & 21.8 & 2.39 & $<0.08$ & $<0.08$ \\
\hline North Basin & 161 & 3204 & $<1.4$ & 667 & 56 & -156 & 9.3 & 1.22 & $<0.08$ & $<0.08$ \\
\hline Gunnison Island & 371 & 7226 & $<1.4$ & 287 & 128 & -114 & 7.9 & 0.19 & $<0.08$ & $<0.08$ \\
\hline
\end{tabular}

a All bulk sediment constituents are reported as dry weight.

as an indicator for SR activity. In addition, a mixture of sodium salts of small organic acids were added as substrates, and $\mathrm{Na}_{2} \mathrm{~S}$ was substituted with $\mathrm{Na}_{2} \mathrm{~S}_{2} \mathrm{O}_{4}(0.2 \mathrm{mM})$ and $\mathrm{TiCl}_{3}(0.25 \mathrm{mM})$ as the reductants to avoid the immediate formation of $\mathrm{FeS}$ when $\mathrm{FeCl}_{2} \cdot 4 \mathrm{H}_{2} \mathrm{O}$ was added (Brandt et al., 2001). For enriching complete SRB oxidizers, this medium was supplied with sodium acetate $(4 \mathrm{mM})$ as the sole substrate. For targeting the total SRB communities, five substrates, including the sodium salts of formate, acetate, butyrate, propionate, and lactate $(4 \mathrm{mM}$ each) were supplied. The medium salinity was adjusted to the ambient level for each site by adding $\mathrm{NaCl}$. Five replicate MPN dilution series (1:10) from $10^{-1}$ to $10^{-12}$ were established in Balch tubes (Bellco, $\mathrm{NJ}$ ) and incubated at $20^{\circ} \mathrm{C}$ (shaken twice per week) in the dark for 14 weeks. All procedures were performed using anaerobic techniques. The presence of SRB was indicated by the formation of black FeS precipitates.

\subsection{RNA extraction, quantification, and generation of $c D N A$}

Frozen $\left(-80{ }^{\circ} \mathrm{C}\right)$ sediment samples were thawed $\left(-20^{\circ} \mathrm{C}\right)$ overnight in the presence of RNAlater-ICE (ThermoFisher, Waltham, MA). Triplicate subsamples ( $400 \mathrm{mg}$ ) of thawed sediment were subjected to RNA extraction, purification, quantification, and conversion to cDNA as previously described (Hamilton et al., 2013). The sediment dry solid content used in RNA extractions was determined by drying the residual material remaining after nucleic acid extraction at $80^{\circ} \mathrm{C}$ for $24 \mathrm{~h}$.

\subsection{Quantitative PCR ( $q P C R)$}

Quantitative PCR (qPCR) was used to estimate the number of archaeal and bacterial 16S rRNA gene templates from GSL sediments. as previously described (Hamilton et al., 2013), using primers 344F/958R (archaeal 16S rRNA; annealing temperature of $61{ }^{\circ} \mathrm{C}$ ) and $1100 \mathrm{~F} /$ 1492R (bacterial 16S rRNA amplicons; annealing temperature of $55^{\circ} \mathrm{C}$ ). The reported $16 \mathrm{~S}$ rRNA gene transcript abundances represent the average and standard deviation of triplicate qPCR assays.

\subsection{PCR amplification of archaeal and bacterial $16 S$ rRNA gene transcripts from $C D N A$}

Purified cDNA was subjected to amplification of archaeal and bacterial 16S rRNA templates using archaeal primers 344F/915R or bacterial primers $1100 \mathrm{~F} / 1492 \mathrm{R}$, as previously described (Hamilton et al., 2013). Amplicons were sequenced by the Research and Testing Laboratory (Lubbock, TX), using a 454 Genome Sequencer FLX System. Post sequence processing was performed with the Mothur (ver. 1.33.1) (Schloss et al., 2009), as previously described (Hamilton et al., 2013). A PHRED score of $>25$ was specified during filtering and remaining sequences were trimmed to a minimum length of 250 bases. Sequences were aligned with SILVA databases specific for each domain and trimmed using a defined start and end site based on inclusion of $85 \%$ of the total sequences. Chimera removal, assignment of operational taxonomic units (OTUs) at a sequence similarity of $97 \%$ using the nearestneighbor method, and sequence subsampling were conducted as previously described (Hamilton et al., 2013). Sequences representing each OTU have been deposited in the NCBI SRA database under accession number SRP074057.

\subsection{Correlation and statistical analysis of measured parameters}

Measurements that were at or below the limits of detection were given a value corresponding to the detection limit divided by the square root of 2 (Helsel, 2010). These values were then used in correlation and statistical analyses. Significance between treatments (where reported) was assessed using two tailed Student $t$-tests assuming equal variance.

\section{Results}

\subsection{Site description and sediment geochemistry}

The eight GSL study locations spanned a porewater salinity gradient of 0.2 to $30.4 \%$ (Fig. 2; Table 1). Sediment $\mathrm{pH}$ ranged from 6.96 to 8.31 and the temperature ranged from 4.7 to $10.1{ }^{\circ} \mathrm{C}$ (Table 1). Porewater $\mathrm{SO}_{4}^{2-}$ and $\mathrm{Cl}^{-}$concentrations co-varied (Table 2 ) and were generally consistent with the $0.05 \mathrm{SO}_{4}^{2-} / \mathrm{Cl}^{-}$molar ratio of marine systems (Langmuir, 1997). However, sediment porewater from the South Shore location had a $\mathrm{SO}_{4}^{2-} / \mathrm{Cl}^{-}$molar ratio of 1.31 , which may be indicative of input from subsurface mirabilite evaporates that have been identified in various locations throughout GSL (Anderson et al., 2014). Further deviations from the $0.05 \mathrm{SO}_{4}^{2-} / \mathrm{Cl}^{-}$molar ratio of marine systems may be due to consumption of $\mathrm{SO}_{4}^{2-}$ by sulfate reducing bacteria, which have been shown to be present and active in GSL sediments (Brandt et al., 2001). The concentration of porewater $\mathrm{SO}_{4}^{2-}$ increased linearly with porewater salinity. Porewater $\mathrm{Fe}^{2+}$ concentrations were below detection $(<1.4 \mu \mathrm{M})$ at all but two sites; Pond $5 \mathrm{C}(8.5 \mu \mathrm{M})$ and Bear River Bay $(2.9 \mu \mathrm{M})$. Porewater $\mathrm{S}^{2-}$ ranged over 1000 -fold (2$3839 \mu \mathrm{M})$ across all sites, with the highest concentrations ( $>1000 \mu \mathrm{M})$ in Bear River Bay and Ogden Bay. Porewater DOC ranged from 15 to $178 \mathrm{mg} / \mathrm{L}$, with the lowest concentration at Pond 5C and highest concentrations ( $>100 \mathrm{mg} / \mathrm{L}$ ) at South Shore, Ogden Bay, and Gunnison Island.

The sediment redox potential ( $a E_{h}$ ) ranged from -3 to $-227 \mathrm{mV}$, with the two most reduced sites Ogden Bay and Bear River Bay $(-227$ and $-163 \mathrm{mV}$, respectively) also exhibiting the highest levels of porewater free sulfide (3.8 and $2.7 \mathrm{mM}$, respectively) (Table 2 ). Sediment TRS, which includes dissolved $\mathrm{S}^{2-}$ and solid phase FeS and $\mathrm{FeS}_{2}$, ranged from 6.0 to $36.3 \mu \mathrm{mol} \mathrm{g}{ }^{-1}$ (dry wt.) and was correlated with 
acid extractable $\mathrm{Fe}^{2+}$ (Pearson's $r=0.80$ ), which is often in the form of FeS (Pyzik and Sommer, 1981). Sediment amorphous and crystalline $\mathrm{Fe}^{3+}$ was generally below detection $\left(<0.08 \mathrm{mg} \mathrm{g}^{-1}\right)$ across all sites, with the exception of Farmington Bay (both fractions) and crystalline $\mathrm{Fe}^{3+}$ at the Pond 3E and South Shore.

Sediment THg concentrations ranged from 7.2 to $382.0 \mathrm{ng} \mathrm{g}^{-1}$ with the percentage of $\mathrm{THg}$ as $\mathrm{Hg}(\mathrm{II})_{\mathrm{R}}$ ranging from 0.1 to $1.7 \%$ and the percentage as MeHg ranging from 0.2 to $8.0 \%$ (Table 3). While sediment $\mathrm{Hg}(\mathrm{II})_{\mathrm{R}}$ concentrations were strongly correlated to $\mathrm{THg}$ concentrations $(r=0.95)$, the correlation between $\mathrm{MeHg}$ and $\mathrm{THg}$ concentrations was poor $(r=0.61)$, a result paralleling other reports that THg alone is a generally weak to poor predictor of $\mathrm{MeHg}$ in sedimentary systems (Heim et al., 2007; Kelly et al., 1995; Scudder et al., 2009). Similarly, the positive correlation between $\mathrm{MeHg}$ and $\mathrm{Hg}(\mathrm{II})_{\mathrm{R}}$ concentration was also comparatively weak $(r=0.56)$.

\subsection{Mercury methylation and demethylation potentials}

First-order rate constants for $\mathrm{Hg}(\mathrm{II})$-methylation ( $\mathrm{k}_{\text {meth }}$ ), derived from ${ }^{200} \mathrm{Hg}$ (II) stable isotope incubations ranged from $<0.001$ (detection limit) to $0.16 \mathrm{day}^{-1}$. When coupled with the independently measured $\mathrm{Hg}(\mathrm{II})_{\mathrm{R}}$ concentration data, a surrogate metric for microbially available Hg(II) (Marvin-DiPasquale et al., 2009; Marvin-DiPasquale et al., 2014), the calculated MPP rates ranged from $<0.1$ (detection limit) to $72.6 \mathrm{pg} \mathrm{g}^{-1} \mathrm{~d}^{-1}$ (dry weight basis) (Table 3 ). Values of $\mathrm{k}_{\text {meth }}$ were strongly correlated with sediment \% THg as $\mathrm{MeHg}(r=0.97)$, a metric commonly cited as a measure of $\mathrm{Hg}$ (II)-methylation efficiency (Domagalski, 2001; Gilmour et al., 1998; Krabbenhoft et al., 1999), and with both values being highest at the two freshwater marsh sites. Values of $\mathrm{k}_{\text {meth }}$ (LOG base 10 transformed) were also negatively correlated with porewater $\mathrm{SO}_{4}^{2-}$ concentrations $(r=-0.78)$ and more weakly negatively correlated with porewater salinity overall $(r=-0.61)$. It is noteworthy that sediment MeHg concentration was more strongly correlated with MPP rates $(r=0.72)$ calculated from both $\mathrm{k}_{\text {meth }}$ and $\mathrm{Hg}(\mathrm{II})_{\mathrm{R}}$ concentration, than with $\mathrm{k}_{\text {meth }}$ values alone $(r=0.30)$. This observation has been reported previously (Marvin-DiPasquale et al., 2009; Marvin-DiPasquale et al., 2014) and speaks to the value of including some independently measured metric for site-specific microbially available $\mathrm{Hg}$ (II) concentration (e.g. $\mathrm{Hg}(\mathrm{II})_{\mathrm{R}}$ ) when assessing potential rates of $\mathrm{Hg}(\mathrm{II})$-methylation.

First order rate constants for degradation of $\mathrm{MeHg}\left(\mathrm{k}_{\mathrm{deg}}\right)$ ranged from $<0.008$ (detection limit) to 0.050 day $^{-1}$ to which when converted to MDP (based on in situ MeHg concentrations) varied from 0.5 to $62.2 \mathrm{pg} \mathrm{g}^{-1} \mathrm{~d}^{-1}$ (dry weight) (Table 3 ). MDP rates were strongly correlated with MPP rates $(r=0.92)$. MPP rates exceeded MDP rates at half of the sites sampled, with the resulting MPP/MDP ratio ranging from 0.01 to 1.74 .

To better define the dominant microbial groups associated with $\mathrm{Hg}$ (II)-methylation along the GSL salinity gradient, a second set of

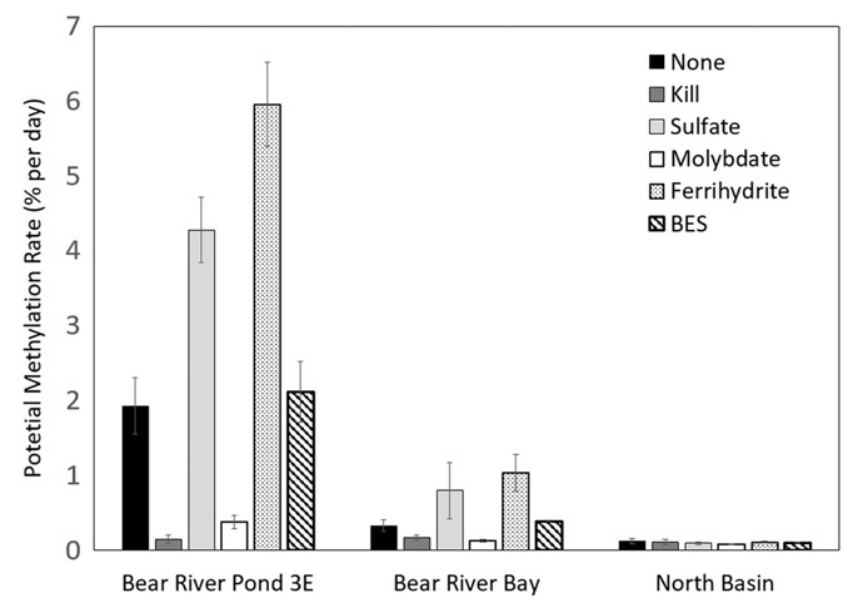

Fig. 3. Sediment $\mathrm{Hg}(\mathrm{II})$-methylation potential rate constant (expressed as percent per day) derived from radioisotope ${ }^{203} \mathrm{Hg}$ (II) incubations from select sites amended with sulfate, molybdate, iron oxyhydroxide (ferrihydrite), or bromoethanesulfonate (BES).

microcosm $\mathrm{Hg}(\mathrm{II})$-methylation rate (MPP) assays were conducted with sediment from a sub-set of the original sampling sites and using radiotracer ${ }^{203} \mathrm{Hg}$ (II) amendments in combination with amendments of $\mathrm{SO}_{4}^{2-}, \mathrm{MoO}_{4}^{2-}, \mathrm{Fe}(\mathrm{OH})_{3}$, or BES (Fig. 3). Radiotracer derived MPP rates for the freshwater marsh site (Bear River Pond 3E) and the brackish open water site (Bear River Bay) were significantly greater than those associated with autoclave sterilized controls $(P<0.01 \& 0.03$, respectively), indicating that $\mathrm{Hg}(\mathrm{II})$-methylation can be attributed to biological activity. Further, MPP rates associated with the hypersaline North Basin sediment were not significantly different $(P=0.65)$ from autoclave sterilized controls (Fig. 3), consistent with the stable isotope MPP rate assessment for this site that was below detection (Table 3). The addition of $\mathrm{SO}_{4}^{2-}$ stimulated MPP rates relative to unamended controls in both Bear River Pond 3E and Bear River Bay $(P=0.01 \& 0.10$, respectively), while MPP rates were significantly suppressed in samples from both sites $(P<0.01 \&<0.01$, respectively $)$ in microcosms amended with $\mathrm{MoO}_{4}^{2-}$, an inhibitor of SRB (Oremland and Taylor, 1978). These results indicate a role for SRB in $\mathrm{Hg}(\mathrm{II})$-methylation in these sediment samples.

Amendment of microcosms with $\mathrm{Fe}(\mathrm{OH})_{3}$ stimulated MPP rates over unamended controls in both Bear River Pond 3E and Bear River Bay sediment microcosms $(P<0.01 \&<0.01$, respectively $)$ and furthermore, this stimulation exceeded the effect of $\mathrm{SO}_{4}^{2-}$ addition (Fig. 3). This indicates that organisms with the capacity to reduce iron are potentially involved in $\mathrm{Hg}$ (II)-methylation in these environments. Importantly, amendment of microcosms with BES, an inhibitor of methanogenesis (Gunsalus et al., 1978), had no noticeable effect on MPP rates. To the extent that microcosm assays reflect in situ conditions, this observation

Table 3

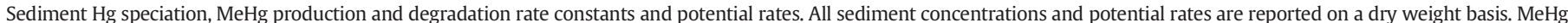

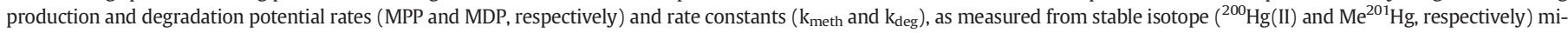
crocosm incubations.

\begin{tabular}{|c|c|c|c|c|c|c|c|c|c|}
\hline Site name & $\begin{array}{l}\text { THg } \\
(\mathrm{ng} / \mathrm{g})\end{array}$ & $\begin{array}{l}\mathrm{Hg}(\mathrm{II})_{\mathrm{R}} \\
(\mathrm{ng} / \mathrm{g})\end{array}$ & $\begin{array}{l}\mathrm{Hg}(\mathrm{II})_{\mathrm{R}} \\
\text { (\% of } \mathrm{THg})\end{array}$ & $\begin{array}{l}\mathrm{MeHg} \\
(\mathrm{ng} / \mathrm{g})\end{array}$ & $\begin{array}{l}\mathrm{MeHg} \\
\text { (\% of THg) }\end{array}$ & $\begin{array}{l}\mathrm{k}_{\text {meth }} \\
(1 / \mathrm{d})\end{array}$ & $\begin{array}{l}\text { MPP rate } \\
(\mathrm{pg} / \mathrm{g} / \mathrm{d})\end{array}$ & $\begin{array}{l}k_{\text {deg }}{ }^{a} \\
(1 / d)\end{array}$ & $\begin{array}{l}\text { MDP rate } \\
(\mathrm{pg} / \mathrm{g} / \mathrm{d})\end{array}$ \\
\hline Bear River - Pond 5C & 52.1 & 0.26 & 0.50 & 1.75 & 3.35 & $1.6 \times 10^{-1}$ & 37.9 & $* 1.3 \times 10^{-2}$ & $* 21.8$ \\
\hline Bear River - Pond 3E & 10.6 & 0.18 & 1.71 & 0.84 & 7.96 & $2.6 \times 10^{-1}$ & 41.6 & $4.5 \times 10^{-2}$ & 37.0 \\
\hline Farmington Bay & 382.0 & 2.31 & 0.60 & 1.69 & 0.44 & $3.2 \times 10^{-2}$ & 72.6 & $3.8 \times 10^{-2}$ & 62.2 \\
\hline Bear River Bay & 37.0 & 0.39 & 1.07 & 0.72 & 1.94 & $5.1 \times 10^{-2}$ & 19.5 & $5.0 \times 10^{-2}$ & 34.9 \\
\hline South Shore & 31.3 & 0.12 & 0.37 & 0.05 & 0.16 & $<1.0 \times 10^{-3}$ & $<0.1$ & $* 9.8 \times 10^{-3}$ & * 0.5 \\
\hline Ogden Bay & 107.0 & 0.44 & 0.41 & 1.17 & 1.10 & $4.6 \times 10^{-2}$ & 20.0 & $* 8.7 \times 10^{-3}$ & $* 10.2$ \\
\hline North Basin & 119.5 & 0.16 & 0.13 & 1.13 & 0.95 & $<1.0 \times 10^{-3}$ & $<0.1$ & $<8.5 \times 10^{-3}$ & $<9.6$ \\
\hline Gunnison Island & 7.2 & 0.03 & 0.47 & 0.05 & 0.68 & $6.2 \times 10^{-3}$ & 0.2 & $* 1.6 \times 10^{-2}$ & $* 0.8$ \\
\hline
\end{tabular}

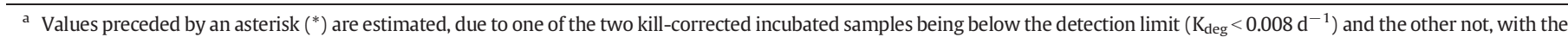

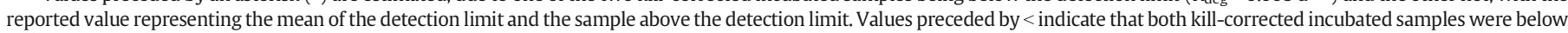
the detection limit. In both situations the MDP rate calculated from $\mathrm{k}_{\mathrm{deg}}$ and in situ $\mathrm{MeHg}$ concentration data is similarly flagged. 
suggests that methanogens contribute little to $\mathrm{Hg}(\mathrm{II})$-methylation in the sampled GSL sediments.

\subsection{Abundance and composition of $16 S$ rRNA transcripts}

qPCR of 165 cDNA was used to estimate population sizes of active archaea and bacteria in GSL sediments. The abundance of archaeal 16S rRNA gene transcript copies ranged from $3.2 \times 10^{2}$ to $7.2 \times 10^{5} \mathrm{~g}^{-1}$ (dry weight) while the corresponding value for bacterial copies ranged from $8.8 \times 10^{3}$ to $3.9 \times 10^{5}$ templates $\mathrm{g}^{-1}$ (Fig. 4 ). The abundance of bacterial 16S rRNA gene transcripts significantly $(P<0.05)$ exceeded archaeal 16S rRNA gene transcripts in all sediment locations with the exception of Bear River Pond 5E where archaeal transcripts exceeded bacterial transcripts and Farmington Bay and South Shore where bacterial transcript numbers exceeded those of archaea, but the differences were not significant. The abundance of bacterial transcripts was inversely correlated with salinity $(r=-0.52)$, with a sharp drop off in transcript abundance observed in sediments sampled from locations with salinity $>7.5 \%$. The abundance of archaeal transcript was not correlated with porewater salinity or other measured parameters with the exception of $\mathrm{MeHg}$ concentrations. Since this correlation was driven primarily by data from a single site (Bear River 3E) it was not further explored.

Archaeal and bacterial cDNA was PCR amplified using 16S rRNAspecific primers and subjected to 454 pyrotag sequencing. A total of 3538 and 8068 sequences were subsampled from each sediment archaeal and bacterial 16S cDNA library, respectively, resulting in coverages of $>88$ and $>89 \%$ of the predicted OTU richness (defined at $97 \%$ sequence identities) based on rarefaction analyses in each of the eight sites, respectively (data not shown). Archaeal sequence assemblages were binned at the order level of taxonomy. With the exception of Bear River Pond 5C (having the lowest porewater salinity, $0.2 \%$ ), all sediment samples were dominated by sequences ( 57.1 to $99.7 \%$ of total) that were most closely affiliated with members of the Halobacteriales (Fig. 5A). The archaeal assemblage associated with sediments from Bear River Pond 5C comprises sequences with close affiliation to the methanogenic orders Methanomicrobiales and Methanosarcinales as well as sequences with distant affiliation with the ammonia oxidizing order Nitrososphaerales. Methanogens were also represented in several of the other communities where they comprised up to $26.5 \%$ of the transcript sequences.

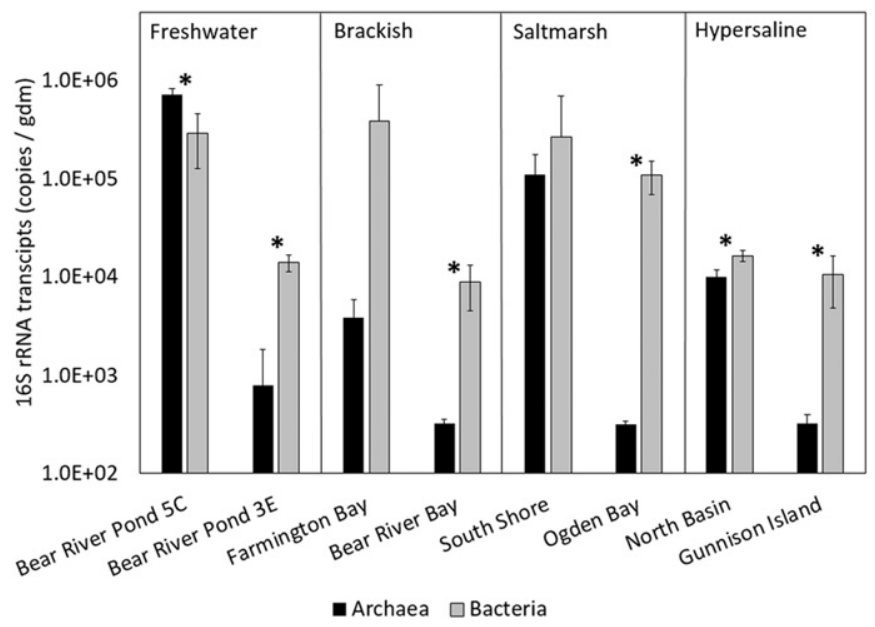

Fig. 4. Abundance of archaeal and bacterial $16 \mathrm{~S}$ rRNA gene transcripts associated with GSL sediment. Results are presented as the average and standard deviation of three replicate measurements. Asterisks denote a significance difference $(P<0.05)$ between archaeal and bacterial transcript abundance in a given site as determined by a Student's $t$-test.
Bacterial 16S rRNA transcript assemblages, when binned at the phylum level, were generally dominated by sequences affiliated with Proteobacteria (34-62\% of total sequences) followed by Bacteroidetes (10-38\% of total sequences) (Fig. 5B). Within the Proteobacteria, sequences exhibiting affiliation with the Deltaproteobacteria and Gammaproteobacteria were most abundant. The abundance of sequences affiliated with these classes did not vary systematically with any of the geochemical measurements. In addition to Proteobacteria, sequences affiliated with Candidatus Calescamantes (North Basin) and Firmicutes (South Shore) were also abundant.

To identify populations that are potentially involved in $\mathrm{Hg}$ (II)-methylation in GSL sediment, the relative abundance of the 20 most abundant archaeal and bacterial 16S rRNA transcript OTUs was subjected to correlation analysis against measured MPP rates and sediment $\mathrm{MeHg}$ concentrations. Two bacterial OTUs were identified whose distribution exhibited a strong positive correlation with MPP, one of which was affiliated with the SRB Desulfobacterium catecholicum (99\% sequence identities) and the other which was affiliated with the purple sulfur photosynthetic bacterium Thioalkalicoccus limnaeus (98\% sequence identities). When converted to the absolute abundance of templates (by multiplying OTU relative abundance by quantitative abundance data from qPCR assays), the abundance of the Desulfobacterium affiliated 16S rRNA OTU (LOG base 10 transformed) was strongly correlated with the stable isotope derived MPP $(r=0.85)$ and with sediment $\mathrm{MeHg}$ concentration $(r=0.72)$ (Fig. $6 \mathrm{~A})$. Likewise, the decay in the abundance of 16S rRNA transcripts affiliated with this Desulfobacterium-affiliated OTU (LOG base 10 transformed) as a function of salinity $(r=-0.70)$ paralleled the decay in the MPP as a function of salinity $(r=-0.60)$ (Fig. 6B), providing additional evidence that this OTU could be involved in $\mathrm{Hg}$ (II)-methylation. Three archaeal OTUs exhibited positive correlations with salinity; these were all closely affiliated with halophilic euryarchaeotes including the genera Halorhabdus (92\% sequence identities), Halogranum (99\% sequence identities), and Halopelagius (97\% sequence identities). Since members of these genera, and the Halobacteria in general, are largely aerobes (Oren, 2006) and are not known to methylate Hg (Parks et al., 2013), these OTUs were not considered further as possible methylators in GSL sediment.

To identify potential $\mathrm{Hg}$ (II)-methylators whose ecological distribution was too narrow (i.e., only present in a single environmental sample) to be detected via the correlation analyses described above, archaeal and bacterial 16S rRNA transcript libraries were also screened for genera that include known or potential $\mathrm{Hg}$ (II)-methylators based on the presence of hgcAB homologs in their genomes (Parks et al., 2013). 16S rRNA OTUs with close affiliation to Desulfobacterium (94$100 \%$ sequence identities) were detected in each of the sediment samples indicating a widespread salinity tolerance for this genus. In addition, a 16S rRNA OTU with close affiliation to the putative $\mathrm{Hg}$ (II)methylating genus Syntrophus (97\% sequence identities) was detected in freshwater sediment from Bear River Pond 5C. This OTU was represented by 15,604 templates $\mathrm{g}^{-1}$ in this environment, as compared to 14,512 Desulfobacterium templates $\mathrm{g}^{-1}$. 16S rRNA OTUs with close affiliation (96-98\% sequence identities) to the putative $\mathrm{Hg}$ (II)-methylator Desulfobulbus were also identified in each of the sediment samples at abundances of up to 2400 templates $\mathrm{g}^{-1}$. Among archaeal sequences, those with close affiliation ( $>92 \%$ sequence identities) to the methanogenic genera Methanoregula, Methanolobus, Methanosphaerula, and Methanomassiliicoccus at abundances of 206,468, 1617, 8089, and 7078 templates $\mathrm{g}^{-1}$ were identified only in freshwater sediment sampled from Bear River Pond 5C.

\subsection{Most probable number (MPN) estimation of SRB}

As a secondary method to determine the relative abundance of SRB in sediment sampled across the GSL salinity gradient, MPN based approaches were applied to sediment slurries collected from Bear River Pond 3E (1.5\% salinity), Bear River Bay (5.6\% salinity), and North Basin 

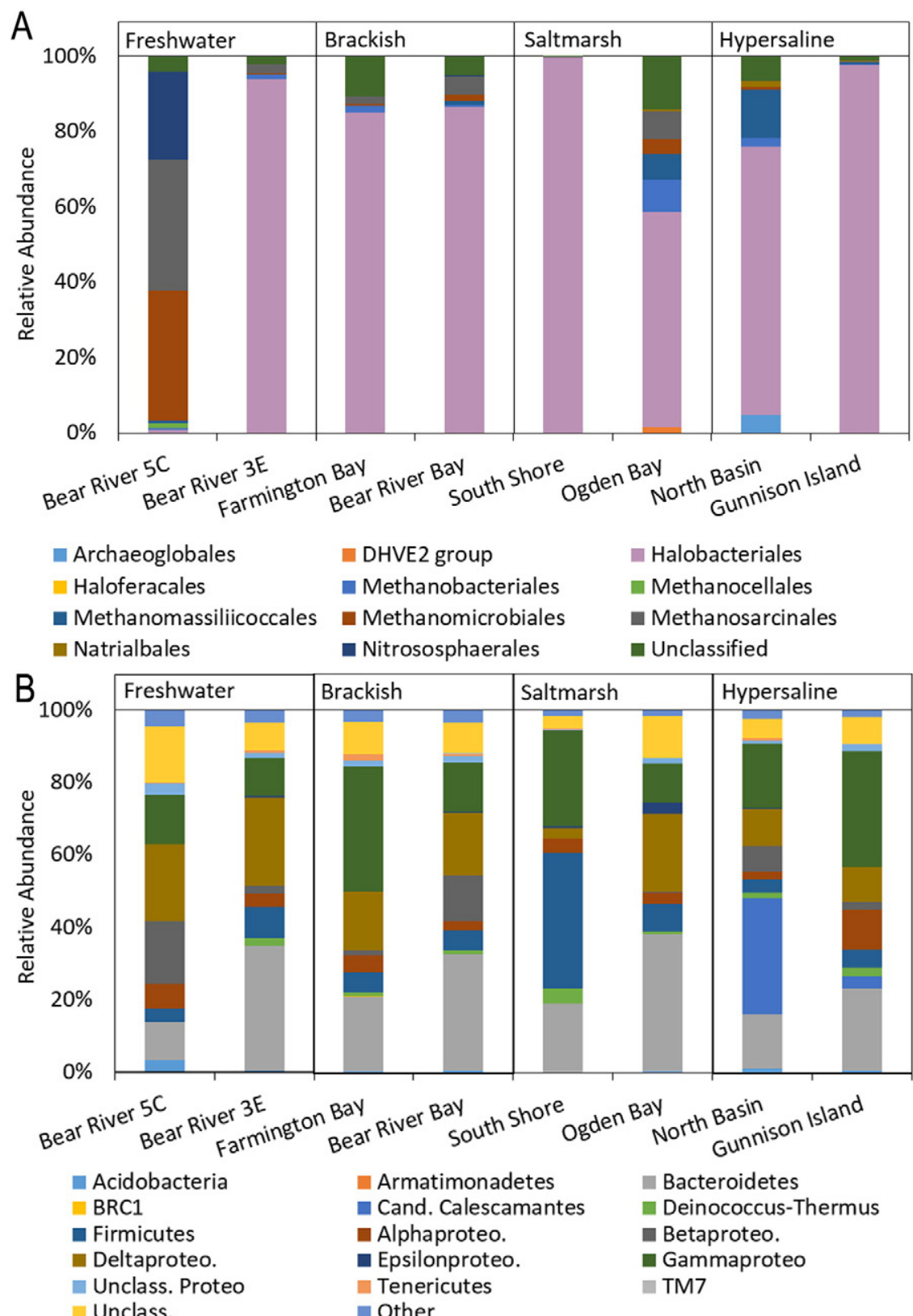

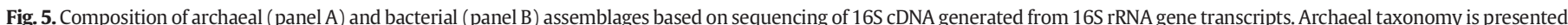

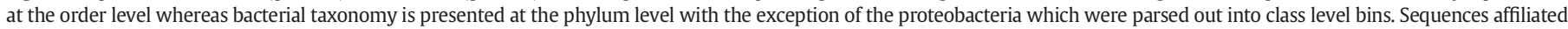

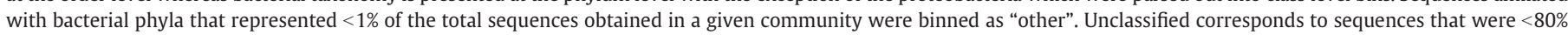
homologous to sequences in the SILVA databases.

(19.0\% salinity). To distinguish between complete and incomplete organic carbon degrading SRBs, MPNs were amended with only acetate or with five organic acids (formate, lactate, propionate, butyrate, and acetate), respectively. Thus, acetate MPNs should quantify complete oxidizing SRB while MPNs from the organic acid mixture should quantify total SRBs under the conditions examined. MPNs amended with acetate ranged from $3.5 \times 10^{2}$ to $5.4 \times 10^{5}$ cells $\mathrm{mL}^{-1}$ of slurry with the lowest MPN observed in sediment sampled from North Basin (Table 4). MPNs amended with the five organic acids ranged from 0 to $5.4 \times 10^{7}$ cells $\mathrm{mL}^{-1}$, again with the lowest MPN observed in sediments sampled from North Basin. In sediment sampled from both Bear River Pond 3E and Bear River Bay, the abundance of total SRB was $~ 2$ to 2.5 orders of magnitude higher than the abundance of complete oxidizers.

\section{Discussion}

In order to identify potential microbial drivers of MeHg in the GSL ecosystem, and controls on its production, we performed a spatial study of the microbial communities and the $\mathrm{Hg}$ chemistry across a salinity gradient. Concentrations of $\mathrm{THg}, \mathrm{Hg}(\mathrm{II})_{\mathrm{R}}$ and $\mathrm{MeHg}$, rates of $\mathrm{Hg}$ (II)methylation ( $k_{\text {meth }}$ and MPP) and MeHg degradation ( $k_{\text {deg }}$ and MDP), and abundances and compositions of archaeal and bacterial 16 rRNA gene transcripts were determined in our sediment samples. Both $\mathrm{k}_{\text {meth }}$ and MPP in sediment-associated communities were inversely correlated with salinity and were near or below the limits of detection in sediments sampled from hypersaline waters. The highest $\mathrm{k}_{\text {meth }}$ and MPP rates were determined in sediment with low porewater salinity, in 

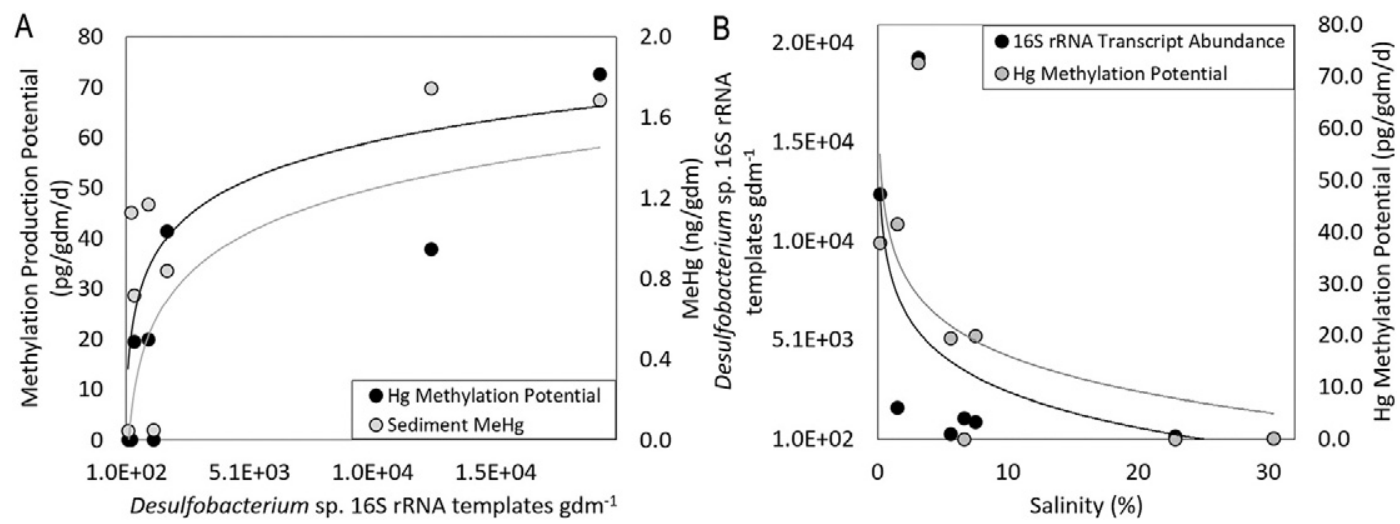

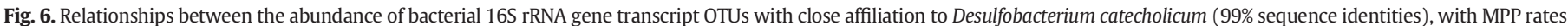

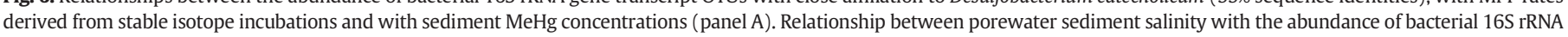
gene transcript OTUs with close affiliation to Desulfobacterium catecholicum (99\% sequence identities), and with MPP rates derived from stale isotope incubations (panel B).

particular the freshwater marshes associated with Bear River Pond 5C and $3 \mathrm{E}$ and the brackish open-water Farmington Bay and Bear River Bay sampling locations (Table 1). These observations suggest that sediment communities inhabiting less saline environments may contribute more MeHg to GSL than those in higher salinity environments and raise intriguing questions as to what factors, biological or abiological, account for this trend.

For $\mathrm{Hg}(\mathrm{II})$ to be methylated it must first be biologically available (Benoit et al., 2003; Hsu-Kim et al., 2013). Current paradigms of $\mathrm{Hg}$ (II) bioavailability to methylators are focused on the complex interactions with sulfides (Benoit et al., 2003) and DOM (Gerbig et al., 2011). These interactions lead to a variety of amorphous, colloidal and aggregated nanoparticle forms of mercuric sulfide (Aiken et al., 2011), some of which could be available to $\mathrm{Hg}$ (II)-methylating microbes (Graham et al., 2012). Alternatively, the enhanced solubility products of some of these compounds might promote $\mathrm{Hg}$ (II)-methylation (Zhang et al., 2012). Our $k_{\text {meth }}$ and MPP results showed little correlation with porewater sulfide ( $r=-0.20$ and -0.18 , respectively) or with DOC ( $r=-0.32$ and -0.45 , respectively) concentrations. Rather, these two measures of methylation activity were negatively correlated with salinity ( $r=-0.57$ and -0.69 , respectively) suggesting salinity may be a dominant factor controlling either $\mathrm{Hg}$ (II) bioavailability or the $\mathrm{Hg}$ (II)-methylating microbial community composition (or activity) in GSL sediment. Clearly the small number of observations $(n=8)$ in the current study limited our ability to develop more sophisticated multivariable statistical models that might well allow for an assessment of the relative influence of the various factors known to influence the $\mathrm{Hg}$ (II)-methylation process (e.g. sulfide, DOC, sulfate/salinity, etc.). Nonetheless, these data are consistent with other studies of $\mathrm{Hg}$ (II)methylation across a salinity gradient which have suggested rates to be higher in low salinity, freshwater ecosystems (Hall et al., 2008; Hsu-Kim et al., 2013).

Table 4

Most probable number estimation of the abundance of complete oxidizer and total SRB in sediments sampled at select locations in GSL.

\begin{tabular}{lll}
\hline Site & Treatment & MPN $\left(\right.$ cells $\left.\mathrm{mL}^{-1}\right)$ \\
\hline Bear River Pond 3E & Acetate $^{\mathrm{a}}$ & $5.4 \times 10^{4}$ \\
& S Organic acids $^{\mathrm{b}}$ & $1.1 \times 10^{7}$ \\
Bear River Bay & Acetate $^{\mathrm{a}}$ & $5.4 \times 10^{5}$ \\
& 5 Organic acids $^{\mathrm{b}}$ & $5.4 \times 10^{7}$ \\
North Basin & Acetate $^{\mathrm{a}}$ & $3.5 \times 10^{2}$ \\
& 5 Organic acids $^{\mathrm{b}}$ & b.d. \\
\hline
\end{tabular}

a Sodium acetate added at a concentration of $4 \mathrm{mM}$.

b Five organic acids included the sodium salts of formate, lactate, propionate, butyrate, and acetate, added at $4 \mathrm{mM}$ each.
Suppression of $\mathrm{Hg}(\mathrm{II})$-methylation in estuarine sediment incubations by sea water salinities was previously reported (Blum and Bartha, 1980; Compeau and Bartha, 1987) and attributed to sulfide inhibition of $\mathrm{Hg}$ (II) availability (Gilmour and Henry, 1991). However, salinity and its effect on the electrochemical charge of the various forms of $\mathrm{Hg}$ (II) also could be of key significance, as elevated salinity increases the proportion of charged $\mathrm{Hg}$ (II) species $\left(\mathrm{HgCl}_{3}^{-} / \mathrm{HgCl}_{4}^{2-}\right)$ relative to uncharged $\mathrm{HgCl}_{2}$ (Barkay et al., 1997). Since uncharged $\mathrm{HgCl}_{2}$ can more readily diffuse across plasma membranes into the cytoplasm where methylation takes place (Bienvenue et al., 1984), lower salinities should promote higher rates of methylation. More recent models of $\mathrm{Hg}$ transport (Hsu-Kim et al., 2013), including facilitated transport (Golding et al., 2002) and active transport (Schaefer et al., 2011), possibly through transporters of essential metals (Szczuka et al., 2015), may also be impacted by the presence of competing ligands in high saline environments. Indeed, the methodologically defined $\mathrm{Hg}(\mathrm{II})_{\mathrm{R}}$ proxy for bioavailable $\mathrm{Hg}(\mathrm{II})$ in GSL sediment was inversely correlated with salinity (albeit weakly, $r=-0.34$ ). Although environments with the extreme salinities observed in some parts of GSL are rare, our findings bear significance for $\mathrm{Hg}$ bioavailability to methylation in the marine environment, a major source of human dietary exposure to toxic $\mathrm{MeHg}$ (Groth, 2010). Our results therefore, call for integration of salinity into models of $\mathrm{Hg}$ bioavailability together with sulfide and DOM concentrations.

Benthic MPP rates in the saltmarsh and hypersaline open-water regions of GSL determined in this study ranged from $<0.1$ to $20 \mathrm{pg} \mathrm{g}^{-1} \mathrm{~d}^{-1}$ with an average of $\sim 5.0 \mathrm{pg} \mathrm{g}^{-1} \mathrm{~d}^{-1}$. These MPP rates are similar to those previously measured in the unconsolidated 'sediment slurry layer' sampled from a series of off-shore transects within both Gunnison Bay (North Arm of GSL) and Gilbert Bay (South Arm of GSL) (0.03-1.37 $\mathrm{pg} \mathrm{g}^{-1} \mathrm{~d}^{-1}$ ) (Johnson et al., 2015), but are low when compared to those from the brackish open-water and freshwater marsh regions within GSL sampled in the current study (19.5$72.6 \mathrm{pg} \mathrm{g}^{-1} \mathrm{~d}^{-1}$ ). These rates are also low compared to freshwater sediment from the San Francisco Bay Delta freshwater wetlands (average $=59.3 \mathrm{pg} \mathrm{g}^{-1} \mathrm{~d}^{-1}$ ) (Marvin-DiPasquale et al., 2014) and sediment from a diversity of freshwater streams (average $=0.14$ to $9.4 \mathrm{pg} \mathrm{g}^{-1} \mathrm{~d}^{-1}$ ) (Marvin-DiPasquale et al., 2009). Low benthic $\mathrm{k}_{\text {meth }}$ values and MPP rates in hypersaline GSL sediment is inconsistent with the high levels of MeHg observed previously in anoxic and sulfidic DBL waters in GSL where levels of salinity are highest (Johnson et al., 2015; Jones and Wurtsbaugh, 2014; Naftz et al., 2009). It has been previously suggested that elevated MeHg in the DBL at GSL was due to an absence of light capable of catalyzing abiotic $\mathrm{MeHg}$ photodegradation (Johnson et al., 2015; Naftz et al., 2011). This is consistent with our previous light meter measurement showing no Photosynthetically Active Radiation (PAR) in the DBL $(0 \mu \mathrm{mol} \cdot$ photons $\cdot \mathrm{m}-2 \cdot \mathrm{s}-)$ compared 
with a measurement ( $44 \mu \mathrm{mol} \cdot$ photons $\cdot \mathrm{m}-2 \cdot \mathrm{s}-$ ) in the less saline water column $1.5 \mathrm{~m}$ above the DBL (Meuser et al., 2013).

Biological MeHg demethylation also represents an important sink for MeHg (Barkay et al., 2003). Under oxic conditions, degradation of MeHg by organomercury lyase (MerB) is thought to be the predominant biological mechanism by which MeHg is degraded (Barkay et al., 2010; Boyd and Barkay, 2012), whereas under anoxic conditions and in systems with elevated $\mathrm{Hg}$ contamination the oxidative $\mathrm{MeHg}$ degradation pathway appears to predominate (Marvin-DiPasquale et al., 2000; Marvin-DiPasquale and Oremland, 1998). While not explicitly investigated in this study, the low redox potentials and elevated $\mathrm{S}^{2-}$ concentrations of GSL sediments suggest that oxidative demethylation likely predominates in this system. In our sediment microcosms, $\mathrm{k}_{\mathrm{deg}}$ values and MDP rates were both inversely correlated with salinity ( $r=-0.43$ and -0.55 , respectively), suggesting that constraints imposed by salinity on oxidative demethylation may also contribute to the persistence of MeHg in the DBL saline environment where $\mathrm{MeHg}$ production rates are low. The ratio of $\mathrm{k}_{\text {meth }} / \mathrm{k}_{\mathrm{deg}}$ or MPP/MDP provides a metric to evaluate the net potential to produce or degrade $\mathrm{MeHg}$ in an environment. Ratios of both $\mathrm{k}_{\mathrm{meth}} / \mathrm{k}_{\mathrm{deg}}$ and MPP/MDP were inversely correlated with salinity $(r=-0.53$ and -0.62 , respectively) and best described with an exponential decay function $\left(R^{2}=0.73\right.$ and 0.43 , respectively) (Supp. Fig. 1). By habitat type, the two freshwater marsh sites had the highest mean $\mathrm{k}_{\text {meth }} / \mathrm{k}_{\mathrm{deg}}$ and MPP/MDP ratios (9.22 and 1.43 , respectively), while the two hypersaline sites had the lowest mean ratios ( 0.25 and 0.14 respectively).

Gradients in salinity are also likely to influence the distribution and ecology of $\mathrm{Hg}$ (II)-methylating microorganisms and thus may contribute to variation in the production and persistence of MeHg in natural systems. The abundance of Syntrophus- and methanogen-related OTUs in the low salinity Bear River Bay sampling location, coupled with a high rate of MPP and elevated concentrations of MeHg, may suggest an important role for syntrophs in $\mathrm{Hg}$ (II) methylation in this environment. This would be similar to what has been observed in some freshwater environments (Bae et al., 2014). However, strong correlations were noted between the absolute abundance of a bacterial 16S rRNA OTU which had a close affiliation with the SRB genus Desulfobacterium and MPP rates $(r=0.85)$ and MeHg concentrations $(r=0.72)$ in GSL sediments. These observations suggest a role for this taxon in $\mathrm{Hg}$ (II)methylation in low salinity GSL sediments. This finding is consistent with previous studies which, on the basis of high rates of SR and elevated concentrations of $\mathrm{SO}_{4}^{2-}$ in GSL waters, predicted that SRB are the primary methylators of $\mathrm{Hg}$ in these ecosystems (Jones and Wurtsbaugh, 2014; Naftz et al., 2009; Wurtsbaugh et al., 2011). Furthermore, a previous study documented $\mathrm{Hg}$ (II)-methylation in Desulfobacterium sp. strain BG-33 and this activity was dependent on the presence of $\mathrm{SO}_{4}^{2-}$ in the cultivation medium (King et al., 2000).

Additional evidence for the role of SRB in $\mathrm{Hg}$ (II)-methylation in GSL sediments comes from ${ }^{203} \mathrm{Hg}$ (II) radiotracer microcosm assays, which revealed enhanced MPP when microcosms were provided with $\mathrm{SO}_{4}^{2-}$ and suppression of $\mathrm{Hg}(\mathrm{II})$-methylation activity when microcosms were provided with molybdate, an inhibitor of SRB (Oremland and Taylor, 1978), relative to unamended controls. However, microcosms provided with iron oxides also exhibited higher rates of MPP relative to unamended controls, suggesting that FeRB might also be involved in $\mathrm{Hg}(\mathrm{II})$-methylation in GSL. Indeed, FeRB have been shown to be involved in $\mathrm{Hg}(\mathrm{II})$-methylation in natural environments (Fleming et al., 2006) and members of the Geobacteraceae are documented methylators (Parks et al., 2013). However, while several of the GSL sediments analyzed contained detectable amorphous and crystalline Fe(III) and acid extractable $\mathrm{Fe}(\mathrm{II})$, bacterial 16S rRNA transcripts affiliated with canonical iron reducers, including Geobacteraceae (Weber et al., 2006), were not recovered. A previous study of the SRB Desulfobacterium autotrophicum revealed the ability of this strain to reduce iron oxides, although it is unclear if this organism can conserve enough energy from this reaction to support growth and whether this particular strain can methylate Hg (Lovley et al., 1993). Regardless, it is possible that the Desulfobacterium OTU identified in GSL sediments with significant correspondence with MPP and sediment MeHg concentrations is capable of reducing both $\mathrm{SO}_{4}^{2-}$ and iron-oxides, perhaps explaining why MPP was stimulated by amendment with both $\mathrm{SO}_{4}^{2-}$ and oxidized iron.

The distribution and abundance of sequences affiliated with Desulfobacterium (family Desulfobacteraceae) were largely constrained to sediments with porewater salinities $<7.5 \%$, although subdominant populations of $16 \mathrm{~S}$ rRNA sequences affiliated with Desulfobacterium were recovered from all of the sampling sites (Supp. Fig. 1). This is consistent with a previous combined molecular- and cultivation-based characterization of SRB at high salinities in GSL (27\% salt) which also identified subdominant sequences affiliated with Desulfobacteraceae (Kjeldsen et al., 2007). Dominant SRB in this environment were affiliated with Desulfohalobium utahense (Jakobsen et al., 2006), which belongs to a family (Desulfohalobiaceae) of SRB that are incomplete oxidizers (Spring et al., 2010). Moreover, physiological characterization of these strains suggest that they are moderate halophiles (growth optima $\sim 10 \%$ salt) that are salt-stressed at salinities above $10 \%$. The dominance of incomplete oxidizer SRB (i.e, Desulfohalobium) as opposed to complete oxidizer SRB (i.e., Desulfobacterium) as a function of high salinity is consistent with a previous compilation of SRB across hypersaline conditions which found that incomplete oxidizer SRB can tolerate salinities up to $24 \%$ and possibly up to $30 \%$, whereas complete oxidizers have been shown to be constrained to environments with $<12 \%$ salt (Oren, 2013). Complete oxidizing SRB can completely oxidize acetate to $\mathrm{CO}_{2}$ to conserve energy and then use the acetyl CoA pathway to assimilate $\mathrm{CO}_{2}$ (Ekstrom and Morel, 2008; Ekstrom et al., 2003). It is now thought that the methyl group from methyl-tetrahydrofolate supplied by the acetyl CoA pathway is transferred to a corrinoid-containing protein complex termed HgcAB, the site of Hg methylation (Parks et al., 2013). BLASTp analysis of the sole complete Desulfobacterium genome available in public databases (i.e., D. autotrophicum) failed to detect homologs of HgcAB. However, the draft genome of D. vacuolatum DSM 3385 encoded for homologs of both HgcAB (Locus tags Ga0002809_12054 and Ga0002809_12054, respectively). This is consistent with previous work demonstrating $\mathrm{Hg}$ (II)-methylation in other Desulfobacterium strains (King et al., 2000) and the acetate dependence of $\mathrm{Hg}$ (II)-methylation in sediment enriched with Desulfobacterium (King et al., 2000).

In addition to MPP, MDP was also strongly correlated with the abundance of 16S rRNA gene transcripts affiliated with Desulfobacterium. Previous studies have shown that SRB and methanogens are responsible for the majority of oxidative MeHg demethylation in anoxic sediments (Marvin-DiPasquale and Oremland, 1998; Oremland et al., 1995), with SRB apparently dominating in estuarine sediments (Oremland et al., 1991). If Desulfobacterium is involved in both $\mathrm{Hg}(\mathrm{II})$-methylation and oxidative demethylation of $\mathrm{MeHg}$, the next critical question becomes what determines the relative importance of $\mathrm{MeHg}$ production and degradation in these organisms since it appears as though both are sensitive to extreme salinity.

The high levels of MeHg in anoxic GSL sediment measured here and in the DBL that at one time overlaid much of the GSL, as determined previously (Johnson et al., 2015; Naftz et al., 2009), pose health risks for aquatic life and avian populations (Naftz et al., 2008; Wurtsbaugh et al., 2011). While it has been previously suggested that SRB in the DBL are responsible for the majority of the MeHg that enters the food chain, data shown here suggests that sediment from lower salinity environments are also a likely source of MeHg in GSL. The extent to which $\mathrm{MeHg}$ makes its way into the aquatic food web is likely more contingent on where $\mathrm{MeHg}$ is formed. For example, whereas $\mathrm{MeHg}$ formed in freshwater sediments likely diffuses into oxic waters where it can be degraded both by biological and abiological (photodegradation) mechanisms, $\mathrm{MeHg}$ that is produced in the DBL is more likely to end up in the food webs of GSL since the primary abiotic degradative pathway is mitigated due to light attenuation (Johnson et al., 2015; Naftz et al., 2011). The persistence of $\mathrm{MeHg}$ in the DBL is likely amplified by constraints 
imposed by salinity on biological MeHg degradation. The near record low elevation and high salinity of the lake in 2016 and efforts to reconstruct the causeway to allow for greater exchange of water between the NA and SA are likely to impact the extent of the DBL (White et al., 2015), which in turn may also impact MeHg production, degradation, and entry into the aquatic food web.

\section{Acknowledgements}

This project was supported by a grant to DLN and MMD and a grant to ESB, TB, and BLB, both from the Utah Department of Natural Resources Division of Forestry, Fire, and State Lands.

\section{Appendix A. Supplementary data}

Supplementary data to this article can be found online at http://dx. doi.org/10.1016/j.scitotenv.2016.12.157.

\section{References}

Aiken, G.R., Hsu-Kim, H., Ryan, J.N., 2011. Influence of dissolved organic matter on the environmental fate of metals, nanoparticles, and colloids. Environ. Sci. Technol. 45 3196-3201.

Aldrich, T.W., Paul, D.S., 2002. Avian ecology of Great Salt Lake. In: Gwynn, J.W. (Ed.) Great Salt Lake: An Overview of Change. Utah Department of Natural Resources, p. 584.

Anderson, R.B., Naftz, D.L., Day-Lewis, F.D., Henderson, R.D., Rosenberry, D.O., Stolp, B.J., et al., 2014. Quantity and quality of groundwater discharge in a hypersaline lake environment. J. Hydrol. 512, 177-194.

Bae, H.-S., Dierberg, F.E., Ogram, A., 2014. Syntrophs dominate sequences associated with the mercury methylation-related gene $h_{c} A$ in the water conservation areas of the Florida Everglades. Appl. Environ. Microbiol. 80, 6517-6526.

Barkay, T., Gillman, M., Turner, R.R., 1997. Effects of dissolved organic carbon and salinity on bioavailability of mercury. Appl. Environ. Microbiol. 63, 4267-4271.

Barkay, T., Kritee, K., Boyd, E., Geesey, G., 2010. A thermophilic bacterial origin and subsequent constraints by redox, light and salinity on the evolution of the microbial mercuric reductase. Environ. Microbiol. 12, 2904-2917.

Barkay, T., Miller, S.M., Summers, A.O., 2003. Bacterial mercury resistance from atoms to ecosystems. FEMS Microbiol. Rev. 27, 355-384.

Barnes, B.D., Wurtsbaugh, W.A., 2015. The effects of salinity on plankton and benthic communities in the Great Salt Lake, Utah, USA: a microcosm experiment. Can. J. Fish. Aquat. Sci. 72, 807-817.

Baxter, B.K., Litchfield, C.D., Sowers, K., Griffith, J.D., Dassarma, P.A., Dassarma, S., 2005. Microbial diversity of Great Salt Lake. Adaptation to Life at High Salt Concentrations in Archaea, Bacteria, and Eukarya. Springer, pp. 9-25.

Beisner, K., Naftz, D.L., Johnson, W.P., Diaz, X., 2009. Selenium and trace element mobility affected by periodic displacement of stratification in the Great Salt Lake, Utah. Sci. Total Environ. 407, 5263-5273.

Benoit, J.M., Gilmour, C.C., Heyes, A., Mason, R.P., MC, L., 2003. Geochemical and Biologica Controls Over Mercury Production and Degradation in Aquatic Systems. American Chemical Society, Washington DC.

Bienvenue, E., Boudou, A., Desmazes, J.P., Gavach, C., Georgescauld, D., Sandeaux, J., et al., 1984. Transport of mercury compounds across bimolecular lipid membranes: Effect of lipid composition, $\mathrm{pH}$ and chloride concentration. Chem. Biol. Interact. 48, 91-101.

Blum, J.E., Bartha, R., 1980. Effect of salinity on methylation of mercury. Bull. Environ. Contam. Toxicol. 25, 404-408.

Boyd, E.S., Barkay, T., 2012. The mercury resistance operon: from an origin in a geothermal environment to an efficient detoxification machine. Front. Microbiol. 3, 349.

Boyd, E.S., Hamilton, T.L., Swanson, K.D., Howells, A.E., Baxter, B.K., Meuser, J.E., et al., 2014. [FeFe]-hydrogenase abundance and diversity along a vertical redox gradient in Great Salt Lake, USA. Int. J. Mol. Sci. 15, 21947-21966.

Boyd, E.S., King, S., Tomberlin, J.K., Nordstrom, D.K., Krabbenhoft, D.P., Barkay, T., et al., 2009. Methylmercury enters an aquatic food web through acidophilic microbial mats in Yellowstone National Park, Wyoming. Environ. Microbiol. 11, 950-959.

Brandt, K.K., Vester, F., Jensen, A.N., Ingvorsen, K., 2001. Sulfate reduction dynamics and enumeration of sulfate-reducing bacteria in hypersaline sediments of the Great Salt Lake (Utah, USA). Microb. Ecol. 41, 1-11.

Cannon, J.S., Cannon, M.A., 2002. The Southern Pacific Railroad trestle - past and present. In: Gwynn, J.W. (Ed.), Great Salt Lake. An Overview of Change. Special Publication of the Utah Department of Natural Resources, Salt Lake City, Utah, pp. 283-294.

Castro, H.F., Williams, N.H., Ogram, A., 2000. Phylogeny of sulfate-reducing bacteria. FEMS Microbiol. Ecol. 31, 1-9.

Collins, N., 1980. Population ecology of Ephydra cinerea Jones (Diptera: Ephydridae), the only benthic metazoan of the Great Salt Lake, USA. Hydrobiologia 68, 99-112.

Compeau, G.C., Bartha, R., 1985. Sulfate-reducing bacteria: Principal methylators of mercury in anoxic estuarine sediment. Appl. Environ. Microbiol. 50, 498-502.

Compeau, G.C., Bartha, R., 1987. Effect of salinity on mercury-methylating activity of sulfate-reducing bacteria in estuarine sediments. Appl. Environ. Microbiol. 53 261-265.
Cornell, R.M., Schwertmann, U., 2003. The Iron Oxides: Structure, Properties, Reactions, Occurences, and Uses. Wiley-VCH, New York

Domagalski, J., 2001. Mercury and methylmercury in water and sediment of the Sacramento River Basin, California. Appl. Geochem. 16, 1677-1691.

Ekstrom, E.B., Morel, F.M., 2008. Cobalt limitation of growth and mercury methylation in sulfate-reducing bacteria. Environ. Sci. Technol. 42, 93-99.

Ekstrom, E.B., Morel, F.M., Benoit, J.M., 2003. Mercury methylation independent of the acetyl-coenzyme A pathway in sulfate-reducing bacteria. Appl. Environ. Microbiol. 69, 5414-5422.

Fleming, E.J., Mack, E.E., Green, P.G., Nelson, D.C., 2006. Mercury methylation from unexpected sources: Molybdate-inhibited freshwater sediments and an iron-reducing bacterium. Appl. Environ. Microbiol. 72, 457-464.

Gerbig, C.A., Kim, C.S., Stegemeier, J.P., Ryan, J.N., Aiken, G.R., 2011. Formation of nanocolloidal metacinnabar in mercury-DOM-sulfide systems. Environ. Sci. Technol. 45, 9180-9187.

Gilmour, C.C., Henry, E.A., 1991. Mercury methylation in aquatic systems affected by acid deposition. Environ. Pollut. 71, 131-169.

Gilmour, C.C., Podar, M., Bullock, A.L., Graham, A.M., Brown, S.D., Somenahally, A.C., et al., 2013. Mercury methylation by novel microorganisms from new environments. Environ. Sci. Technol. 47, 11810-11820.

Gilmour, C.C., Riedel, G.S., Ederington, M.C., Bell, J.T., Gill, G.A., Stordal, M.C., 1998. Methylmercury concentrations and production rates across a trophic gradient in the northern Everglades. Biogeochemistry 40, 327-345.

Golding, G.R., Kelly, C.A., Sparling, R., Loewen, P.C., Rudd, J.W.M., Barkay, T., 2002. Evidence for facilitated uptake of $\mathrm{Hg}$ (II) by Vibrio anguillarum and Escherichia coli under anaerobic and aerobic conditions. Limnol. Oceanogr. 47, 967-975.

Graham, A.M., Aiken, G.R., Gilmour, C.C., 2012. Dissolved organic matter enhances microbial mercury methylation under sulfidic conditions. Environ. Sci. Technol. 46, 2715-2723.

Groth 3rd., E., 2010. Ranking the contributions of commercial fish and shellfish varieties to mercury exposure in the United States: implications for risk communication. Environ. Res. 110, 226-236.

Gunsalus, R.P., Romesser, J.A., Wolfe, R.S., 1978. Preparation of coenzyme M analogs and their activity in the methyl coenzyme M reductase system of Methanobacterium thermoautotrophicum. Biochemistry 17, 2374-2377.

Hall, B.D., Aiken, G.R., Krabbenhoft, D.P., Marvin-DiPasquale, M., Swarzenski, C.M., 2008. Wetlands as principal zones of methylmercury production in southern Louisiana and the Gulf of Mexico region. Environ. Pollut. 154, 124-134.

Hamilton, T.L., Peters, J.W., Skidmore, M.L., Boyd, E.S., 2013. Molecular evidence for an active endogenous microbiome beneath glacial ice. ISME J. 7, 1402-1412.

Heim, W.A., Coale, K.H., Stephenson, M., Choe, K.Y., Gill, G.A., Foe, C., 2007. Spatial and habitat-based variations in total and methyl mercury concentrations in surficial sediments in the San Francisco Bay-Delta. Environ. Sci. Technol. 41, 3501-3507.

Helsel, D., 2010. Much ado about next to nothing: Incorporating nondetects in science. Ann. Occup. Hyg. 54, 257-262.

Hines, M.E., Faganeli, J., Adatto, I., Horvat, M., 2006. Microbial mercury transformations in marine, estuarine and freshwater sediment downstream of the Idrija Mercury Mine, Slovenia. Appl. Geochem. 21, 1924-1939

Hsu-Kim, H., Kucharzyk, K.H., Zhang, T., Deshusses, M.A., 2013. Mechanisms regulating mercury bioavailability for methylating microorganisms in the aquatic environment: A critical review. Environ. Sci. Technol. 47, 2441-2456.

Huffman, R.L., Wagner, R.J., Toft, J., Cordell, J., DeWild, J.F., Dinicola, R.S., et al., 2012. Mercury species and other selected constituent concentrations in water, sediment and biota of Sinclair Inlet, Kitsap County, Washington, 2007-2010. U.S. Geol. Surv. 64

Jakobsen, T.F., Kjeldsen, K.U., Ingvorsen, K., 2006. Desulfohalobium utahense sp. nov., a moderately halophilic, sulfate-reducing bacterium isolated from Great Salt Lake. Int. J. Syst. Evol. Microbiol. 56, 2063-2069.

Johnson, W.P., Swanson, N., Black, B., Rudd, A., Carling, G., Fernandez, D.P., et al., 2015. Total- and methyl-mercury concentrations and methylation rates across the freshwater to hypersaline continuum of the Great Salt Lake, Utah, USA. Sci. Total Environ. 511, 489-500.

Jones, E.F., Wurtsbaugh, W.A., 2014. The Great Salt Lake's monimolimnion and its importance for mercury bioaccumulation in brine shrimp (Artemia franciscana). Limnol. Oceanogr. 59, 141-155.

Keck, W., Hassibe, W., 1979. The Great Salt Lake. In: USG (Ed.), Survey, p. 25

Kelly, C.A., Rudd, J.W.M., St.Louis, V.L., Heyes, A., 1995. Is total mercury concentration a good predictor of methyl mercury concentration in aquatic systems? Water Air Soil Pollut 80, 715-724.

King, J.K., Kostka, J.E., Frischer, M.E., Saunders, F.M., 2000. Sulfate-reducing bacteria methylate mercury at variable rates in pure culture and in marine sediments. Appl. Environ. Microbiol. 66, 2430-2437.

Kjeldsen, K.U., Loy, A., Jakobsen, T.F., Thomsen, T.R., Wagner, M., Ingvorsen, K., 2007. Diversity of sulfate-reducing bacteria from an extreme hypersaline sediment, Great Salt Lake (Utah). FEMS Microbiol. Ecol. 60, 287-298.

Krabbenhoft, D.P., Wiener, J.G., Brumbaugh, W.G., Olson, M.L., DeWild, J.F., Sabin, T.J., 1999. A National Pilot Study of Mercury Contamination of Aquatic Ecosystems Along Multiple Gradients. pp. 147-160.

Langmuir, D., 1997. Aqueous Environmental Geochemistry. Vol. 8. Prentice Hall, Upper Saddle River, New Jersey.

Lovley, D.R., Roden, E.E., Phillips, E.J.P., Woodward, J.C., 1993. Enzymatic iron and uranium reduction by sulfate-reducing bacteria. Mar. Geol. 113, 41-53.

Marvin-DiPasquale, M., Agee, J., McGowan, C., Oremland, R.S., Thomas, M., Krabbenhoft, D., et al., 2000. Methyl-mercury degradation pathways: A comparison among three mercury-impacted ecosystems. Environ. Sci. Technol. 34, 4908-4916.

Marvin-DiPasquale, M., Lutz, M.A., Brigham, M.E., Krabbenhoft, D.P., Aiken, G.R., Orem, W.H., et al., 2009. Mercury cycling in stream ecosystems. 2. Benthic methylmercury 
production and bed sediment-pore water partitioning. Environ. Sci. Technol. 43 2726-2732.

Marvin-DiPasquale, M., Windham-Myers, L., Agee, J.L., Kakouros, E., Kieu, L.H., Fleck, J.A., et al., 2014. Methylmercury production in sediment from agricultural and nonagricultural wetlands in the Yolo Bypass, California, USA. Sci. Total Environ. 484, 288-299.

Marvin-DiPasquale, M.C., Lutz, M.A., Krabbenhoft, D.P., Aiken, G.R., Orem, W.H., Hall, B.D. et al., Mercury, T., 2008. Methylmercury, methylmercury production potential, and ancillary streambed-sediment and pore-water data for selected streams in Oregon, Wisconsin, and Florida, 2003-04. U.S. Geophys. Surv. 25.

Marvin-DiPasquale, M.C., Oremland, R.S., 1998. Bacterial methylmercury degradation in Florida Everglades peat sediment. Environ. Sci. Technol. 32, 2556-2563.

Mason, R.P., Reinfelder, J.R., Morel, F.M.M., 1996. Uptake, toxicity, and trophic transfer of mercury in a coastal diatom. Environ. Sci. Technol. 30, 1835-1845.

Meuser, J.E., Baxter, B.K., Spear, J.R., Peters, J.W., Posewitz, M.C., Boyd, E.S., 2013. Contrasting patterns of community assembly in the stratified water column of Great Salt Lake, Utah. Microb. Ecol. 66, 268-280.

Naftz, D., Angeroth, C., Kenney, T., Waddell, B., Darnall, N., Silva, S., et al., 2008. Anthropogenic influences on the input and biogeochemical cycling of nutrients and mercury in Great Salt Lake, Utah, USA. Appl. Geochem. 23, 1731-1744.

Naftz, D., Fuller, C., Cederberg, J., Krabbenhoft, D., Whitehead, J., 2009. Mercury inputs to Great Salt Lake, Utah: reconnaissance-phase results. Nat. Resour. Environ. Iss. 15, 5.

Naftz, D.L., Carling, G.T., Angeroth, C., Freeman, M., Rowland, R., Pazmiño, E., 2014. Density-stratified flow events in Great Salt Lake, Utah, USA: implications for mercury and salinity cycling. Aquat. Geochem. 20, 547-571.

Naftz, D.L., Cederberg, J.R., Krabbenhoft, D.P., Beisner, K.R., Whitehead, J., Gardberg, J., 2011. Diurnal trends in methylmercury concentration in a wetland adjacent to Great Salt Lake, Utah, USA. Chem. Geol. 283, 78-86.

Oremland, R.S., Culbertson, C.W., Winfrey, M.R., 1991. Methylmercury decomposition in sediments and bacterial cultures: Involvement of methanogens and sulfate reducers in oxidative demethylation. Appl. Environ. Microbiol. 57, 130-137.

Oremland, R.S., Miller, L.G., Dowdle, P., Connell, T., Barkay, T., 1995. Methylmercury oxidative degradation potentials in contaminated and pristine sediments of the carson river, nevada. Appl. Environ. Microbiol. 61, 2745-2753.

Oremland, R.S., Taylor, B.F., 1978. Sulfate reduction and methanogenesis in marine sediments. Geochim. Cosmochim. Acta 42, 209-214.

Oren, A., 2006. The Order Halobacteriales. In: Dworkin, M., Falkow, S., Rosenberg, E. Schleifer, K.-H., Stackebrandt, E. (Eds.), The Prokaryotes: Volume 3: Archaea. Bacteria: Firmicutes, Actinomycetes. Springer New York, New York, NY, pp. 113-164.

Oren, A., 2013. Life at High Salt Concentrations. In: Rosenberg, E., DeLong, E.F., Lory, S. Stackebrandt, E., Thompson, F. (Eds.), The Prokaryotes: Prokaryotic Communities and Ecophysiology. Springer, Berlin Heidelberg, Berlin, Heidelberg, pp. 421-440.

Pak, K.-R., Bartha, R., 1998. Mercury methylation and demethylation in anoxic lake sediments and by strictly anaerobic bacteria. Appl. Environ. Microbiol. 64, 1013-1017.

Parks, J.M., Johs, A., Podar, M., Bridou, R., Hurt, R.A., Smith, S.D., et al., 2013. The genetic basis for bacterial mercury methylation. Science 339, 1332-1335.

Paul, D.S., Manning, A.E., 2008. Great Salt Lake Waterbird Survey Five-Year Report (1997-2001). 2016. Great Salt Lake Ecosystem Program and Utah Division of Wildlife Resources.

Peterson, C., Gustin, M., 2008. Mercury in the air, water and biota at the Great Salt Lake (Utah, USA). Sci. Total Environ. 405, 255-268.

Pickhardt, P.C., Fisher, N.S., 2007. Accumulation of inorganic and methylmercury by freshwater phytoplankton in two contrasting water bodies. Environ. Sci. Technol. 41, 125-131.

Podar, M., Gilmour, C.C., Brandt, C.C., Soren, A., Brown, S.D., Crable, B.R., et al., 2015. Global prevalence and distribution of genes and microorganisms involved in mercury methylation. Sci. Adv. 1.

Protection FDoE, 2011. Analysis of Methyl Mercury in Sediment and Tissue by KOH/ $\mathrm{CH}_{3} \mathrm{OH}$ Digestion Followed by Aqueous Phase Ethylation. Florida Department of Environmental Protection, p. 24.
Pyzik, A.J., Sommer, S.E., 1981. Sedimentary iron monosulfides: Kinetics and mechanism of formation. Geochim. Cosmochim. Acta 45, 687-698.

Rabus, R., Hansen, T.A., Widdel, F., 2013. Dissimilatory sulfate- and sulfur-reducing prokaryotes. In: Rosenberg, E., DeLong, E.F., Lory, S., Stackebrandt, E., Thompson, F. (Eds.), The Prokaryotes: Prokaryotic Physiology and Biochemistry. Springer, Berlin Heidelberg, Berlin, Heidelberg, pp. 309-404.

Roberts, A.J., 2013. Avian diets in a saline ecosystem: Great Salt Lake, Utah, USA. Hum. Wildl. Interact. 7, 158-168.

Schaefer, J.K., Rocks, S.S., Zheng, W., Liang, L., Gu, B., Morel, F.M.M., 2011. Active transport substrate specificity, and methylation of $\mathrm{Hg}(\mathrm{II})$ in anaerobic bacteria. Proc. Natl. Acad. Sci. U. S. A. 108, 8714-8719.

Schloss, P.D., Westcott, S.L., Ryabin, T., Hall, J.R., Hartmann, M., Hollister, E.B., et al., 2009. Introducing mothur: Open-source, platform-independent, community-supported software for describing and comparing microbial communities. Appl. Environ. Microbiol. 75, 7537-7541.

Scholl, D.J., Ball, R.W., 2005. An Evaluation of Mercury Concentrations in Waterfowl From the Great Salt Lake, Utah for 2004 and 2005. 20. Utah Department of Health.

Scudder, B.C., Chasar, L.C., Wentz, D.A., Bauch, N.J., Brigham, M.E., Moran, P.W., et al., 2009 Mercury in fish, bed sediment, and water from streams across the United States, 1998-2005. In: USG (Ed.), Survey, p. 74.

Spencer, R.J., Eugster, H.P., Jones, B.F., Rettig, S.L., 1985. Geochemistry of Great Salt Lake, Utah I: Hydrochemistry since 1850. Geochim. Cosmochim. Acta 49, 727-737.

Spring, S., Nolan, M., Lapidus, A., Glavina Del Rio, T., Copeland, A., Tice, H., et al., 2010. Complete genome sequence of Desulfohalobium retbaense type strain $(\mathrm{HR}(100)(\mathrm{T}))$ Stand. Genomic Sci. 2, 38-48.

Szczuka, A., Morel, F.M.M., Schaefer, J.K., 2015. Effect of thiols, zinc, and redox conditions on Hg uptake in Shewanella oneidensis. Environ. Sci. Technol. 49, $7432-7438$.

Tayler, P.L., Hutchinson, L.A., Muir, M.K., 1980. Heavy metals in the Great Salt Lake, Utah. Utah Geological and Mineral Survey. Bulletin 116, 195-200.

Vest, J.L., Conover, M.R., Perschon, C., Luft, J., Hall, J.O., 2009. Trace element concentrations in wintering waterfowl from the Great Salt Lake, Utah. Arch. Environ. Contam. Toxicol. 56, 302-316.

Watras, C.J., Back, R.C., Halvorsen, S., Hudson, R.J.M., Morrison, K.A., Wente, S.P., 1998. Bioaccumulation of mercury in pelagic freshwater food webs. Sci. Total Environ. 219 183-208.

Weber, K.A., Achenbach, L.A., Coates, J.D., 2006. Microorganisms pumping iron: anaerobic microbial iron oxidation and reduction. Nat. Rev. Microbiol. 4, 752-764.

White, J.S., Null, S.E., Tarboton, D.G., 2015. How do changes to the railroad causeway in Utah's Great Salt Lake affect water and salt flow? PLoS One 10, e0144111.

Widdel, F., Bak, F., 1992. Gram-Negative Mesophilic Sulfate-Reducing Bacteria. In: Balows, A., Trüper, H.G., Dworkin, M., Harder, W., Schleifer, K.-H. (Eds.), The Prokaryotes: A Handbook on the Biology of Bacteria: Ecophysiology, Isolation, Identification. Applications. Springer New York, New York, NY, pp. 3352-3378.

Wurtsbaugh, W.A., Gardberg, J., Izdepski, C., 2011. Biostrome communities and mercury and selenium bioaccumulation in the Great Salt Lake (Utah, USA). Sci. Total Environ. 409, 4425-4434.

Wurtsbaugh, W.A., Gliwicz, Z.M., 2001. Limnological control of brine shrimp population dynamics and cyst production in the Great Salt Lake, Utah. Hydrobiologia 466 119-132.

Yu, R.-Q., Adatto, I., Montesdeoca, M.R., Driscoll, C.T., Hines, M.E., Barkay, T., 2010 Mercury methylation in Sphagnum moss mats and its association with sulfatereducing bacteria in an acidic Adirondack forest lake wetland. FEMS Microbiol. Ecol. 74, 655-668.

Yu, R.-Q., Flanders, J.R., Mack, E.E., Turner, R., Mirza, M.B., Barkay, T., 2012. Contribution of coexisting sulfate and iron reducing bacteria to methylmercury production in freshwater river sediments. Environ. Sci. Technol. 46, 2684-2691.

Zhang, T., Kim, B., Levard, C., Reinsch, B.C., Lowry, G.V., Deshusses, M.A., et al., 2012. Methylation of mercury by Bacteria exposed to dissolved, nanoparticulate, and microparticulate mercuric sulfides. Environ. Sci. Technol. 46, 6950-6958. 